\title{
Multifaceted Aspects of Metabolic Plasticity in Human Cholangiocarcinoma: An Overview of Current Perspectives
}

\author{
Mirella Pastore ${ }^{1}$, Giulia Lori ${ }^{1}$, Alessandra Gentilini ${ }^{1}{ }^{\circledR}$, Maria Letizia Taddei ${ }^{1}{ }^{\circledR}$, \\ Giovanni Di Maira ${ }^{1}$, Claudia Campani ${ }^{1}$, Stefania Recalcati ${ }^{2}$, Pietro Invernizzi ${ }^{3}{ }^{\mathbb{D}}$, \\ Fabio Marra ${ }^{1}$ (D) and Chiara Raggi ${ }^{1, *}$ \\ 1 Department of Experimental and Clinical Medicine, University of Florence, 50134 Florence, Italy; \\ mirella.pastore@unifi.it (M.P.); giulia.lori@unifi.it (G.L.); alessandra.gentilini@unifi.it (A.G.); \\ marialetizia.taddei@unifi.it (M.L.T.); giovanni.dimaira@unifi.it (G.D.M.); \\ claudiacampani.cc@gmail.com (C.C.); fabio.marra@unifi.it (F.M.) \\ 2 Department of Biomedical Sciences for Health, University of Milan, 20133 Milan, Italy; \\ stefania.recalcati@unimi.it \\ 3 Division of Gastroenterology and Center for Autoimmune Liver Diseases, San Gerardo Hospital, \\ Department of Medicine and Surgery, University of Milan-Bicocca, 20900 Monza, Italy; \\ pietro.invernizzi@unimib.it \\ * Correspondence: chiara.raggi@unifi.it; Tel.: +39-055-2758-092
}

Received: 27 January 2020; Accepted: 26 February 2020; Published: 3 March 2020

\begin{abstract}
Cholangiocarcinoma (CCA) is a deadly tumor without an effective therapy. Unique metabolic and bioenergetics features are important hallmarks of tumor cells. Metabolic plasticity allows cancer cells to survive in poor nutrient environments and maximize cell growth by sustaining survival, proliferation, and metastasis. In recent years, an increasing number of studies have shown that specific signaling networks contribute to malignant tumor onset by reprogramming metabolic traits. Several evidences demonstrate that numerous metabolic mediators represent key-players of CCA progression by regulating many signaling pathways. Besides the well-known Warburg effect, several other different pathways involving carbohydrates, proteins, lipids, and nucleic acids metabolism are altered in CCA. The goal of this review is to highlight the main metabolic processes involved in the cholangio-carcinogeneis that might be considered as potential novel druggable candidates for this disease.
\end{abstract}

Keywords: cholangiocarcinoma; mitochondria; OXPHOS; PGC- $1 \alpha$; tricarboxylic acid cycle; fatty acids; fatty acid synthase

\section{Introduction}

Cholangiocarcinoma (CCA), first identified by Steiner and Higginson [1] belongs to a heterogeneous group of malignancies that occur at any point of the biliary tree [2]. It can generate from epithelial cells in the biliary tracts (ie cholangiocytes) and peribiliary glands [3] and, possibly, from progenitor cells or even hepatocytes [4]. Based on the anatomical site, CCAs is classified in two major groups: intrahepatic (iCCA) and extrahepatic (eCCA) CCA [5]. The iCCA is located in the intrahepatic biliary tree $[5,6]$ whereas eCCA may rise in the extrahepatic bile ducts $[7,8]$. CCA is characterized by very poor outcome, showing an increase in incidence and mortality rate worldwide [9-11]. Potentially curative surgical treatment is restricted to the small subset of patients with early stage disease (approximately 35\%). At present, the available medical therapeutic treatments for advanced or metastatic CCA have limited beneficial efficacy [12]. 
Several risk factors, related to chronic biliary inflammation and/or cholestasis, such as primary sclerosing cholangitis, have been associated with higher risk of CCA development [13]. Chronic hepatitis B and C, cirrhosis, alcohol excess, smoke, obesity and diabetes are mainly associated with the development of CCA $[9,14]$. Several epidemiological reports have shown an increase in global occurrence (up to 10 folds) and mortality for iCCA, whereas the incidence for eCCA remained either unchanged or slightly decreased [15-19]. CCA is mainly diagnosed in an advanced clinical stage of the disease, when curative treatment is generally unsuccessful [20]. This is in part due to the lack of clinical manifestation of the tumor in the early stage, especially in case of iCCA, and in part to the absence of specific and sensitive biomarkers. To reduce global mortality from cholangiocarcinoma, efforts must be multifaceted and focus on prevention, early identification of high-risk individuals and prompt diagnosis as well as molecular based targeted therapies for established disease [14].

In this scenario, the concept of tumor metabolism is worth particular interest for several reasons: (i) metabolic modification is a well-known hallmark of cancer, (ii) oncogenes drive alterations in cancer metabolism, (iii) metabolites can control gene and protein expressions, and (iv) metabolic proteins and/or metabolites represent diagnostic and prognostic biomarkers [21-25]. Indeed tumour cells have unique metabolic and bioenergetic features, allowing them to survive in poor nutrient environments and maximize cell growth [22]. Besides glucose metabolism, many other different metabolic pathways that involve carbohydrates, proteins, lipids and nucleic acids are deregulated in cancer cells. Furthermore, tumour cells are able to shift between different metabolic pathways depending on their energetic needs, environmental stress and other factors. Due to the high heterogeneity in the metabolic pathways that occur in different tumors, and even inside the same tumour [26], this review will highlight the main metabolic processes that occur in CCA progression.

\section{Glucose Metabolism and CCA}

The first reported example of a reprogrammed metabolic pathway in cancer is the Warburg effect or aerobic glycolysis $[27,28]$ by which tumour cells mainly convert pyruvate to lactate through glycolysis even when oxygen is abundant [26]. The increase in glycolytic flux allows glycolytic intermediates to supply secondary pathways in order to satisfy the metabolic demands of proliferating cells [27]. Warburg effect is in large part induced by the transcription factors hypoxia inducible factor 1 alpha (HIF-1 $\alpha$ ) and c-Myc but also, in lesser extent, by other signaling pathways, such as the phosphatidylinositol 3-kinase (PI3K)-Akt mammalian target of rapamycin (mTOR) signaling, and the activation of oncogenes and inactivation of tumor suppressors [26].

Recently, it has been recognized that Warburg effect in cancer cells is not a general phenomenon. Indeed, it has been described also a "reverse" Warburg effect, by which tumour cells induce oxidative stress in surrounding stromal fibroblasts, that activates aerobic glycolysis with production of high levels of lactate, which is exported out and recaptured by the tumor. On turn, cancer cells convert the lactate back into pyruvate, which can be used in the tricarboxylic acid (TCA) cycle to fuel oxidative phosphorylation. This theory of "lactate shuttle" between cancer and stromal cells proposes the involvement of the stroma in influencing tumour metabolism [29-32].

A strict dependence of CCA cells on glucose is proved by several papers reporting an increase in the expression levels of the glucose transporter GLUT-1 associated to this disease. Recently Kubo Y. et al., described that the survival of patients with GLUT-1-positive tumors were significantly poorer than those of patients with GLUT-1-negative ones. Moreover, GLUT-1 silencing was able to decrease migration and invasion of CCA cells [33]. Coherently, also Ikeno $\mathrm{Y}$ et al., observed a significantly poorer survival of patients with high GLUT-1 expressing CCA with respect to patients with low GLUT-1 expression [34]. Other authors suggest that CCA cells are heavily dependent on glucose consumption. Suzuki H. et al., showed that GLUT-1 expression correlates with 18F-2-fluoro-2-deoxy-D-glucose uptake in the primary iCCA. Furthermore, high numbers of GLUT-1-positive cells in the tumor samples were found in patients with poorly differentiated carcinoma, confirming a correlation between GLUT-1 expression and histological differentiation [35] (Table 1). 
Table 1. Major altered metabolism pathways in cholangiocarcinoma.

\begin{tabular}{|c|c|c|c|}
\hline Metabolic Pathways & Metabolic Target & Effects on Cholangiocarcinoma (CCA) & Reference \\
\hline \multirow{10}{*}{ Glucose metabolism } & GLUT-1 upregulation & $\begin{array}{l}\text { Correlation with in vitro CCA cell invasion. } \\
\text { Correlation with larger tumor size, poor differentiation, metastasis and poor prognosis of CCA. }\end{array}$ & [33-35] \\
\hline & PPP upstimulation & Sustainment of both the antioxidant capacity of CCA cells and cisplatin resistance. & [36] \\
\hline & PDK overexpression & High serum PDK3 levels correlate with short survival of patients with CCA. PDK1 expression promotes glycolysis and CCA cell proliferation. & [37] \\
\hline & $\begin{array}{l}\text { SIRT3 effects mediated by } \\
\text { HIF1 } \alpha / \text { PDK1/PDHA1 pathway }\end{array}$ & $\begin{array}{l}\text { Decrease of SIRT3 expression induced the glycolytic flux through the hypoxia inducible factor } \alpha(\mathrm{HIF} 1 \alpha) / \mathrm{PDK} 1 / \text { PDHA1 axis, promoting CCA } \\
\text { progression. }\end{array}$ & [38] \\
\hline & $\begin{array}{l}\text { Deregulation of } \\
\text { PI3K-AKT-mTOR signaling }\end{array}$ & $\begin{array}{l}\text { Protein overexpression and activation of PI3K have been associated with tumor progression, differentiation, nodal involvement and reduced OS. } \\
\text { Upregulation of activated form of AKT have been reported in neoplastic cells compared to the surrounding normal tissue; Increased } m \text { TOR gene } \\
\text { copy number and elevated phospho-mTOR levels have been described in biliary cancer specimens in comparison to the adjacent normal or } \\
\text { dysplastic epithelium. } \\
\text { PTEN loss has been related to poor tumor differentiation, nodal involvement and shorter survival in CCA. }\end{array}$ & [39-42] \\
\hline & SIRT2 overexpression & $\begin{array}{l}\text { SIRT2 and its downstream target CMYC, were overexpressed both in human CCA cell lines and in } 48 \text { CCA samples compared to adjacent tissues, } \\
\text { The SIRT2/cMYC pathway is able to reprogram CCA metabolism through inhibition of OXPHOS and activation of SSP to counteract ROS } \\
\text { production, thus protecting CCA cells from oxidative stress-induced apoptosis. }\end{array}$ & [43] \\
\hline & UCP2 overexpression & Up-regulation of UCP2 sustains the EMT and cell invasion of CCA cells. & [44] \\
\hline & FXR downregulation & $\begin{array}{l}\text { Initiation and progression of CCA, and the downregulation of FXR expression could promote cancer development, modulating the energy } \\
\text { metabolism of CCA cells. }\end{array}$ & [45] \\
\hline & PPAR- $\alpha$ upregulation & Tumor occurrence and progression in CCA patients with. & {$[46,47]$} \\
\hline & IDH1 and IDH2 mutations & Increase of glucose uptake and glucose metabolism as well as upregulation of some metabolites in TCA cycle. Upregulation of PFKP. & [48] \\
\hline \multirow{2}{*}{$\begin{array}{l}\text { Mitochondrial } \\
\text { metabolism }\end{array}$} & PGC1 $\alpha$ upregulation & Promotion of CCA metastasis both in vitro and in vivo. & [49] \\
\hline & Sirt1/FOXO1 stimulation & Involvement in autophagy and mitochondrial dysfunction in CCA cells. & [50] \\
\hline \multirow{4}{*}{ Lipid metabolism } & FASN down-regulation & In human and mouse iCCA tissues FASN expression was down- regulated respect to non-tumor adjacent tissues. & [51] \\
\hline & $\begin{array}{c}\text { FA transporter } \\
\text { (SLC27A1) overexpression }\end{array}$ & SCL27A1 silencing in CCA cell lines led to a decrease of cells growth. & [52] \\
\hline & $\begin{array}{c}\text { FA transporter } \\
\text { (FABP5) over expression }\end{array}$ & Correlation with worse prognosis in eCCA. & [53] \\
\hline & COX-2 upregulation & Promotion of CCA growth and invasion. & [54-58] \\
\hline \multirow{3}{*}{ Protein metabolism } & Glutamine depletion & $\begin{array}{l}\text { Strong depletion: induction a cessation of proliferation or cell death (in vitro addiction to glutamine). } \\
\text { Gradual reduction: eCCA cells (EGI-1 and TFK-1) could proliferate under long-term glutamine withdrawal overcoming their addiction to } \\
\text { glutamine. }\end{array}$ & [59] \\
\hline & ASS deficiency & Reduction of arginine in the surrounding tumor cells could lead to a reduction in CCA cell proliferation. & [60] \\
\hline & LAT1 overexpression & Activation of mTOR pathway thus affecting cell proliferation and viability. & [61-63] \\
\hline \multirow{3}{*}{ Iron Metabolism } & TfR1 high expression & Contribution to CCA progression and poorer clinical outcomes. & [64] \\
\hline & Ferritin high expression & Negative prognostic index for CCA patients. & [65] \\
\hline & Fpn reduced mRNA levels & $\begin{array}{l}\text { Reduction of iron release, in tumor cells of CCA patients sample compared to matched surrounding liver, suggests that elevated iron content is a } \\
\text { negative prognostic factor. }\end{array}$ & [65] \\
\hline
\end{tabular}


Along these lines, Saengboonmee C. et al., [66] clearly reported a direct link between high glucose levels in culture media and CCA cell aggressiveness, in term of increased rates of cell proliferation, adhesion, migration and invasion with respect to CCA cells cultured in normal glucose. Indeed, high glucose levels stimulated both the phosphorylation and the nuclear translocation of the signal transducer and activator of transcription 3 (STAT3). In turn, STAT3 up-regulated the transcription of downstream target genes associated with an aggressive phenotype, including cyclin D1, vimentin and matrix metalloproteinase-2. Moreover, tumor tissues from CCA patients with diabetes mellitus showed increased levels of phospho-STAT3, confirming the link between high glucose patient blood and STAT3 activation. In agreement, glucose reduction or STAT3 inhibition reduced the proliferative effect on CCA cells [66]. More recently, the same authors reported the effects of high glucose concentrations on O-GlcNAcylation protein expression and metastatic potentials of CCA cells. Indeed, Phoomak C. et al., [67] described a marked increase of migration and invasion of highly metastatic CCA cell lines when cultured in high glucose medium. In this condition, high glucose uptake may support glucose flux through the hexosamine biosynthesis pathway (HBP) to produce uridine diphospho-N-acetylglucosamine, a substrate for glycosylation, such as O-GlcNAcylation. The flux of the HBP can be regulated by the expression of the rate-limiting enzyme, glucosamine-fructose-6-phosphate amidotransfrase (GFAT), whose levels are upregulated in CCA cell lines maintained in high glucose condition and in tissue samples from patients correlated with high levels of O-GlcNAcylated proteins. Interestingly, both O-GlcNAcylation of vimentin and its stability were increased in CCA cells cultured in high glucose and correlated with improved migratory abilities. Conversely, administration of a GFAT inhibitor suppressed glucose-induced O-GlcNAcylation, vimentin expression and reversed tumor cell invasion [67].

In keeping with an amplified flux of glycolysis, several evidences suggest an increase of lactate levels, the final product of the Warburg metabolism, in CCA. Indeed, increased expression of LDH-A, the nicotinamide adenine dinucleotide (NADH)-dependent enzyme that catalyses the conversion of pyruvate to lactate, was associated with shorter survival of CCA patients [68]. In line, a study conducted by $\mathrm{Yu}$ Y et al., showed that lactate dehydrogenase A (LDH-A) was overexpressed in 52 of 54 (96\%) paraffin-embedded cancer tissues from iCCA patients. Moreover, LDH-A silencing inhibited cell growth and promoted HUCCT1 cell death [69].

The pentose phosphate pathway (PPP), that directs glucose flux to produce nicotinamide adenine dinucleotide phosphate (NADPH) and ribose-5-phosphate, is crucial in CCA metabolism. Qu X et al., [36] demonstrated that, in human CCA QBC939 cells, cisplatin resistance was linked to a high ability to uptake glucose, to generate lactate and to increase the activity of PPP. Indeed, PPP stimulation can be related to an improved flow of autophagy and to an increase in the antioxidant capacity of QBC939 cells, sustaining drug resistance. In line, autophagy inhibition, strongly decreased glucose-6 phosphate dehydrogenase activity, the first enzyme of PPP, and reduced both the NADPH/NADP and reduced glutathione/oxidized glutathione ratio in QBC939 cells. These events caused a drop in the antioxidant capacity of QBC939 cells and a consequent burst of intracellular reactive oxygen species (ROS), leading to an increased sensitivity to cisplatin treatment [36] (Table 1).

Other studies support the up-regulation of Warburg metabolism in CCA: pyruvate dehydrogenase kinases (PDKs) are Ser/Thr kinases that phosphorylate/inactivate mitochondrial pyruvate dehydrogenase, thus decreasing the oxidation of pyruvate in the tricarboxylic acid (TCA) cycle and increasing the Warburg effect [70]. Sanmai S. et al., [37] demonstrated that PDK1, PDK2 and PDK3, were significantly overexpressed in 15 CCA tissues compare to normal ones. Moreover, PDK3 expression levels were considerably higher in CCA sera compared with the benign biliary diseases and healthy groups. In agreement, PDK3 levels correlated with a short survival time in CCA [37]. Overall, these data suggest that inhibition of mitochondrial metabolism and hence the sustenance of the glycolytic flux can be fundamental in CCA growth.

Also Xu L., et al., pointed out a central role of PDK regulation in CCA: in this manuscript the authors demonstrated that in CCA the decrease of SIRT3 expression induced the glycolytic flux through 
the hypoxia inducible factor $\alpha(\mathrm{HIF} 1 \alpha) / \mathrm{PDK} 1 /$ pyruvate dehydrogenase (PDHA1) axis, promoting tumor progression. In particular, SIRT3, a NAD+ dependent deacetylase, inhibited the Warburg effect through HIF1 $\alpha$ deacetylation/destabilization. Indeed, it is known that lysine acetylation is able to regulate the stability of several proteins, including HIF1 $\alpha$. Reduced HIF1 $\alpha$ stability inhibits glycolysis and down-regulates PDK1. The authors showed that in CCA cells, as well as in both tissue samples and in a xenograft model, SIRT3 was downregulated and the glycolysis enhanced. Conversely, the induction of SIRT3 was able to efficiently reduce tumor proliferation via an anti-Warburg effect mediated by the HIF1 $\alpha /$ PDK1/PDHA1 pathway [38] (Table 1).

Overall these data highlight a marked increase in the glycolytyic flux and in lactate production of CCA cells with respect to benign ones. The enhancement of these metabolic pathways may be instrumental for cancer cells to acquire epithelial to mesenchymal transition (EMT) markers for tumor progression as well as to sustain divergent pathways, such as PPP, in order to guarantee both biosynthetic intermediates to mantain cell proliferation and the antioxidant capacity to counteract oxidative stress $[36,66,67]$.

Despite these data showing a marked dependence of on Warburg metabolism, Dan Li et al., demonstrated that PGC1 $\alpha$ overexpression reversed the effect and increased pyruvate flux into the mitochondria by up-regulating both pyruvate dehydrogenase E1 alpha 1 Subunit and mitochondrial pyruvate carrier 1 expression. These events induced mitochondrial biogenesis and the metabolic switch to oxidative phosphorylation (OXPHOS), finally facilitating CCA cells migration and invasion [49]. Collectively all these data suggest a great ability of CCA cells to shift between different metabolic pathways in order to adapt to environmental changes and to survive. Probably the achievement of an OXPHOS metabolism is mandatory to acquire a more aggressive phenotype of CCA cells, facilitating the maintenance of stemness features and the improvement of the metastatic abilities. Thus, we may suppose that Warburg metabolism and OXPHOS contribute at different times or on distinct subpopulation during CCA progression. This evidence could also explain the conflicting data concerning the use of Metformin, an inhibitor of the mitochondrial respiratory chain (complex I) and hence of OXPHOS, with the onset/development of CCA.

In particular, it has been observed that Metformin significantly reduced the risk of iCCA in diabetic patients by $60 \%$ [71,72]. In keeping, also Jiang X. et al., proved that in a xenograft tumor model, Metformin significantly inhibited cell growth in vivo, resulting in decreased tumor volume and weight [73]. Moreover, CCA patients treated with Metformin showed reduced tumor size and improved postoperative survival [73]. On the contrary, Yang Z. et al., [74] have shown that Metformin, even if it is able to reduce cancer cell proliferation and to induce cell cycle arrest, did not improve the survival of CCA patients with diabetes [75].

Thus, further studies are still required to clarify whether Metformin as well as other metabolic drugs could be successfully used in clinic for CCA treatment.

\section{Lipid Metabolism in CCA}

The largest part of normal tissues obtains lipids through the uptake of free fatty acids (FFAs) and lipoproteins from the bloodstream. Nevertheless, it has been described that many cancers showed a reactivation of de novo lipid synthesis, together with an increased expression of several key enzymes [76-80] similarly to embryonic tissue.

However, the role of fatty acid synthase (FASN) in the liver is different in HCC and CCA development. Li et al., [81] have demonstrated that in hepatocellular cell lines, FASN silencing strongly affected proliferation rate, together with apoptosis increase [81]. Moreover, in a hydrodynamic injection mouse model FASN downregulation totally abrogated AKT-dependent hepatocarcinogenesis [81], thus FASN plays a key role in HCC development. Nevertheless, in human and mouse iCCA tissues FASN expression was down- regulated respect to non-tumor adjacent tissues. Indeed, it has been observed that in AKT/Ras mice, which develop both HCC and iCCA, FASN knocking-down prevented only HCC onset $[51,82]$ (Table 1). 
Although lipid metabolism is pivotal for tumor development, CCA seems to be totally independent on de novo fatty acids (Fas) synthesis [81]. Indeed Li et al., [81] have further analyzed the involvement of exogenous FAs uptake. They demonstrated how the deprivation of lipoprotein in culture media highly inhibited CCA cells growth [81]. In addition, the expression levels of FAs transporters such as cluster of differentiation 36 (CD36) and solute carrier family 27 member 1 (SLC27A1) were upregulated in AKT/notch-intracellular domain liver tumor tissues. These results were confirmed in human iCCA samples, where SLC27A1 was overexpressed respect to normal tissues. Moreover, SCL27A1 silencing in both HUCCT1 and HuH28 cell lines led to a decrease of cells growth [52]. This reduction of CCA cells proliferation also synergized with FASN knocking down [81] (Table 1).

Many evidences have demonstrated that FAs are actively transported through cell membrane by specific proteins, the fatty acid transport proteins (FATPs). In the liver, the main proteins involved in this transport are FATP2, FATP1 and FATP5, the fatty acid binding proteins (FABP1, FABP4, and FABP5), and the translocase CD36. In particular, FABP5 seems to play distinct role in iCCA and eCCA. A recent research suggests that FABP5 upregulation characterizes eCCA, reflecting its worse prognosis respect to iCCA. This difference may be due to distinct embryological tissues origin and histological location during carcinogenesis [53] (Table 1).

Recently, it has been demonstrated that adipocytes contribute to EMT, invasion, proliferation and progression, in several cancer types [83-87]. Nie et al., [88] found that co-culture with adipocytes led CCA cells to express mesenchymal biomarkers overexpression and cell-to-cell adhesion alteration. The acquisition of these mesenchymal markers in CCA cells could be due to adypocite-derived FAs. In fact, they showed that the adipocyte-derived FABP4 mediated migration, invasion and lipid accumulation in CCA, by shifting FAs between adipocytes and cancer cells [88].

Even sphingolipids, phospoinositides and eicosanoids derive from FAs. Eicosanoids are generated from arachidonic acid that is converted into prostaglandin $\mathrm{H}_{2}$ by cyclooxygenases (COX1 and COX2) [89]. Recent evidences have demonstrated that prostaglandins (PG) play a key role in CCA onset. In fact, in CCA cells and pre-cancerous bile duct lesions has been observed an up-regulation of COX-2 levels respect to normal bile duct cells [54-58]. In addition, in CCA cells COX-2 overexpression increases $\mathrm{PGE}_{2}$ production, promoting tumor growth $[90,91]$, whereas COX-2 down-regulation with molecular or pharmacological techniques lowers PGE2 release and prevents cancer development and invasion, both in vitro and in vivo tests [55,58,90-94]. Most of the cellular functions depend on lipids availability, thus lipid biosynthesis is strictly regulated to avoid lipid toxicity and membrane dysfunction $[95,96]$.

Importanly, sphingosine-1-phosphate is a pivotal regulator of cell proliferation and survival. The enzyme sphingosine kinase (SPHK) converts the sphingolipid sphingosine to S1P, regulating cell fate. It has been demonstrated that the isoform 1 of SPHK is involved in tumor proliferation, angiogenesis and transformation [97,98]. Chen et al. [99] identified SPHK1 overexpression as a marker of poor prognosis for iCCA. They demonstrated that the inhibition of SPHK1 with SK1-I induces apoptosis in CCA cell lines, together with growth arrest. Moreover SK1-I intraperitoneal injection in CCA xenograft mouse model, leads to a significant suppression of tumor growth [99]. This preclinical study has provided a rationale for clinical trials in CCA patients. ABC294640 is an inhibitor of SPHK2 $(\mathrm{Ki}=9 \mu \mathrm{M}, 3.4 \mu \mathrm{g} / \mathrm{mL})$ that depletes S1P promoting autophagy and/or apoptosis in tumor cells [100-102]. Based on its strong preclinical profile, a first-in-human phase I trial was undertaken to analyze the drug's safety, and to identify the maximum tolerated dose. This study was conducted in 22 patients with solid tumors. Interestingly, the best outcome was a partial response in CCA patients [103] (Table 2). 
Table 2. Metabolic targeted therapy in CCA.

\begin{tabular}{|c|c|c|}
\hline Target & Glucose Metabolism & Reference \\
\hline \multirow{3}{*}{ mTOR } & Everolimus & [104-107] \\
\hline & Sirolimus & {$[108,109]$} \\
\hline & Everolimus + CisGem & [110] \\
\hline \multirow{5}{*}{ PI3K } & LY294002 & [111] \\
\hline & Buparlisib & [112] \\
\hline & PI-103 & [113] \\
\hline & Buparlisib + mFOLFOX6 & [114] \\
\hline & Copanlisib \pm GemorCisGem & [115] \\
\hline \multirow[t]{2}{*}{$\mathrm{AKT}$} & MK2206 & [116] \\
\hline & AG-120 & [117] \\
\hline \multirow[t]{3}{*}{ IDH1 } & AG-221 & [118] \\
\hline & AGI-5198 & [48] \\
\hline & Lipid Metabolism & \\
\hline SPHK2 & ABC294640 & [100-103] \\
\hline \multirow[t]{2}{*}{ HMGCR } & Simvastatin, Atorvastatin & [119] \\
\hline & Protein Metabolism & \\
\hline \multirow{2}{*}{ LAT1 } & 2-aminobicyclo-(2,2,1)-heptane-2-carboxylic acid & [62] \\
\hline & JPH203 & [63] \\
\hline ASS & ADI-PEG 20 & {$[120,121]$} \\
\hline
\end{tabular}

In addition, statins are a class of drugs that inhibiting HMG-CoA reductase, lead to a reduction of serum cholesterol. Several studies have demonstrated that statins are also able to inhibit growth and induce apoptosis in several cancer cells. Buranrat et al., [119] showed that Simvastatin and Atorvastatin exert an antiproliferative action by inhibiting HMG-CoA reductase and p21 activation. Moreover, these statins induced CCA cell death acting through caspase 3 and cytochrome c, inhibited cell migration and reduced colony formation ability of CCA cell lines [119] (Table 2). All these data suggest that statins could be also used for cancer chemoprevention or chemotherapy [8].

\section{Protein Metabolism and CCA}

Usually cancer cells metabolize glucose to produce ATP through aerobic glycolysis but they have to use other energy sources such as glutamine to satisfy fast proliferation [122].

Glutamine is a non-essential ammino-acid, which plays a critical role in cell growth and proliferation acting in the synthesis of other non-essential amino acids, in the modification of chromatin, in the anti-oxidative defense, in the synthesis of nucleotides as nitrogen donor and in the refueling of the TCA cycle intermediate (anaplerosis) [59]. While the role of anaplerosis has been demonstrated in HCC its role in CCA is unknown [60] (Table 1).

Due to continuous loss, replenishment of TCA intermediates is necessary in cancer cells, and this fact causes increased glutamine consumption. A reduction in extracellular glutamine concentration has been demonstrated in most malignancies and it seems to have a role on the cell susceptibility to different apoptosis triggers. Indeed cells starving glutamine are more sensitive to Fas ligand, tumor necrosis factor- $\alpha$ (TNF- $\alpha$ ) and heat shock-mediated apoptosis [122].

The role of glutamine has been studied also in CCA. A paper evaluating glutamine level in CCA and the effects of its deprivation on therapeutic response has been recently published [59]. The study demonstrated a strong depletion of glutamine in the tumor core region of the majority of the samples and this reduction was found to induce a cessation of proliferation or cell death (in vitro addiction to glutamine). In a later part of the study a gradual reduction of external glutamine concentrations has been evaluated. This part of the experiment suggested that eCCA cells (EGI-1 and TFK-1) could proliferate under long-term glutamine withdrawal overcoming their addiction to glutamine. Moreover, 
this study demonstrated that double-deprivation stress through cyclic hypoxia and nutrient starvation eliminates hypoxia-induced chemoresistance to cisplatin thanks to a reduced c-Myc expression [59].

Several transporters mediate the passage of glutamine across the plasma membrane and mitochondrial inner membrane. L-type amino acid transporter 1 (LAT1), a $\mathrm{Na}^{+}$-independent neutral amino acid transporter, is overexpressed and plays a critical role in various human cancers, including CCA [61] (Table 1). For this reason, LAT1 has been evaluated as a target of CCA treatment.

Janpipatkul et al., demonstrated that KKU-M213 cells (CCA cells derived from Thai patients with iCCA) treated with 2-aminobicyclo-(2,2,1)-heptane-2-carboxylic acid had a reduction in L-leucine uptake that consequently inhibits mTOR pathway activity and therefore reduces cell proliferation and viability. Similar results were obtained with LAT1 knockdown KKU-M213 cells [62] (Table 2).

Yothaisong et al., in another work demonstrated the role of JPH203 in inhibiting LAT1 transport activity. This compound suppressed amino acid uptake and CCA cell growth through altering the cell cycle distribution patterns and inducing apoptosis [63] (Tables 1 and 2).

Arginine is a semiessential amino acid synthesized from citrulline in two steps: argininosuccinate synthetase (ASS) converts citrulline and aspartate in argininosuccinate that is later converted to arginine by argininosuccinate lyase.

Argininosuccinate synthetase deficiency has been demonstrated in various malignancies such as melanoma, prostate cancer, pancreatic cancer, renal cell carcinoma, HCC and CCA [120].

Tumor cells that have low ASS expression are unable to synthetise arginine and must depend on extracellular arginine. On the basis of this knowledge, it has been hypothesized that a reduction of arginine in the surrounding tumor cells could lead to a reduction in cell proliferation. ADI-PEG 20 is a cloned arginine-degrading enzyme (arginine deaminase) conjugated with polyethylene glycol that degrades arginine to citrulline. The role of ADI-PEG 20 has been evaluated in patients with advanced HCC with good results in a phase II trial, whereas the phase III trial did not met its primary endpoint [121] (Table 2). ADI-PEG20 has been studied also in patients with CCA where the treatment significantly inhibited growth of RmCCA-1 and HuCCA cells by decreasing both the percentage of viable cells and the proliferative activity in a dose-dependent manner [120].

Arginine is also a substrate of the urea cycle, a metabolic process that occurs exclusively in the liver. The urea cycle transforms ammonia in urea that is less toxic for the organism. Various studies have shown that the urea cycle is altered both in HCC and CCA. A suppression of members of the urea cycle, probably due to epigenetic alterations, has been demonstrated in HCC [123].

Changes in the expression and metabolism of other amino acids compared to healthy patients or patients with other malignancies have also been reported in CCA.

Murakami et al., demonstrated that a multi-omics approach, integrating metabolomic and transcriptomic datasets, was able to distinguish between iCCA and HCC tumours. Regarding amino acids metabolism four amino acids (Lys, Pro, Leu and IIe) were more diversely expressed in iCCA/iCCA-non tumor than in HCC and HCC-non tumor [124].

\section{CCA and Iron}

Iron is necessary for cellular replication and growth, so it is an essential element for life. However, excess iron can facilitate the formation of the most reactive and toxic forms of oxidants through the Fenton reaction [125]. The regulation of cellular iron homeostasis is due to different proteins: the transferrin receptor (TfR1), responsible for transferrin-bound iron up-take, major players in ferroportin (Fpn), the only cellular iron exporter, and ferritin, the iron store protein [126]. An association between high body iron content and cancer in the general population has been demonstrated [127], as well as positive relation between increased body iron stores and the risk of liver cancer [128] (Table 1).

It has been shown also a relationship between liver iron and CCA. In particular, it was demonstrated that high expression of TfR1, with consequent iron uptake, contributes to CCA progression and poorer clinical outcomes [64] (Table 1). Accordingly, it has been showed that high ferritin expression in epithelial cells from CCA patients is a negative prognostic index (6) (Table 1). Moreover, in line with 
these findings, it has been found significantly reduced Fpn mRNA levels, that means reduced iron release, in tumor cells of CCA patients sample compared to matched surrounding liver, suggesting that elevated iron content is a negative prognostic factor [65] (Table 1).

In general, the alterations of iron trafficking in cancer cells lead to iron acquisition or decrease iron release (the high iron needs of tumor cells to sustain cell proliferation) and it has been shown that these alterations of cellular iron metabolism are dependent on the direct action of tumor suppressors and oncogenes [129].

Recently, it has also been shown that increased iron retention in CCA-cancer stem cells (CSCs) could be a novel metabolic factor involved in CCA growth [65]. In particular, it has been shown that CSCs have a phenotype symptomatic of elevated cellular iron content and oxidative stress; increased iron levels are accompanied by important changes in the expression of stemness markers, such as EMT markers, in these cells that can be reversed by iron removal. This finding was mirrored by data showing a trend toward shorter survival in CCA patients with iron levels.

Finally, it has to be noted that CCA-CSCs, despite higher levels of iron and ROS, seem to be less susceptible to the ferroptosis, a recently characterized mechanism which causes cell death through iron-dependent ROS production and lipid peroxidation [130], than CCA cells. This finding could be perhaps due to the well-known CSC resistance to various types of chemoterapeutic agents.

All the observations reported here regarding CCA and iron seem to suggest a hopefully translation into an effective adjunct therapeutic approach based on iron deprivation that should be provided.

\section{Molecular Aspects Underlying CCA Metabolism}

In recent years, an increasing number of studies have elucidated how metabolism is altered in cancer cells, based on observations that components of signal transduction pathways frequently regulate cell metabolism (Figure 1). Tumor cells select mutations that enhance signal transduction through pathways that converge upon a set of metabolic processes that contribute to tumorigenic process. The rewiring of cancer cells metabolism includes abnormalities in glucose homeostasis and other nutrients such as aminoacid and lipid and impairment of mitochondrial function [22]. 


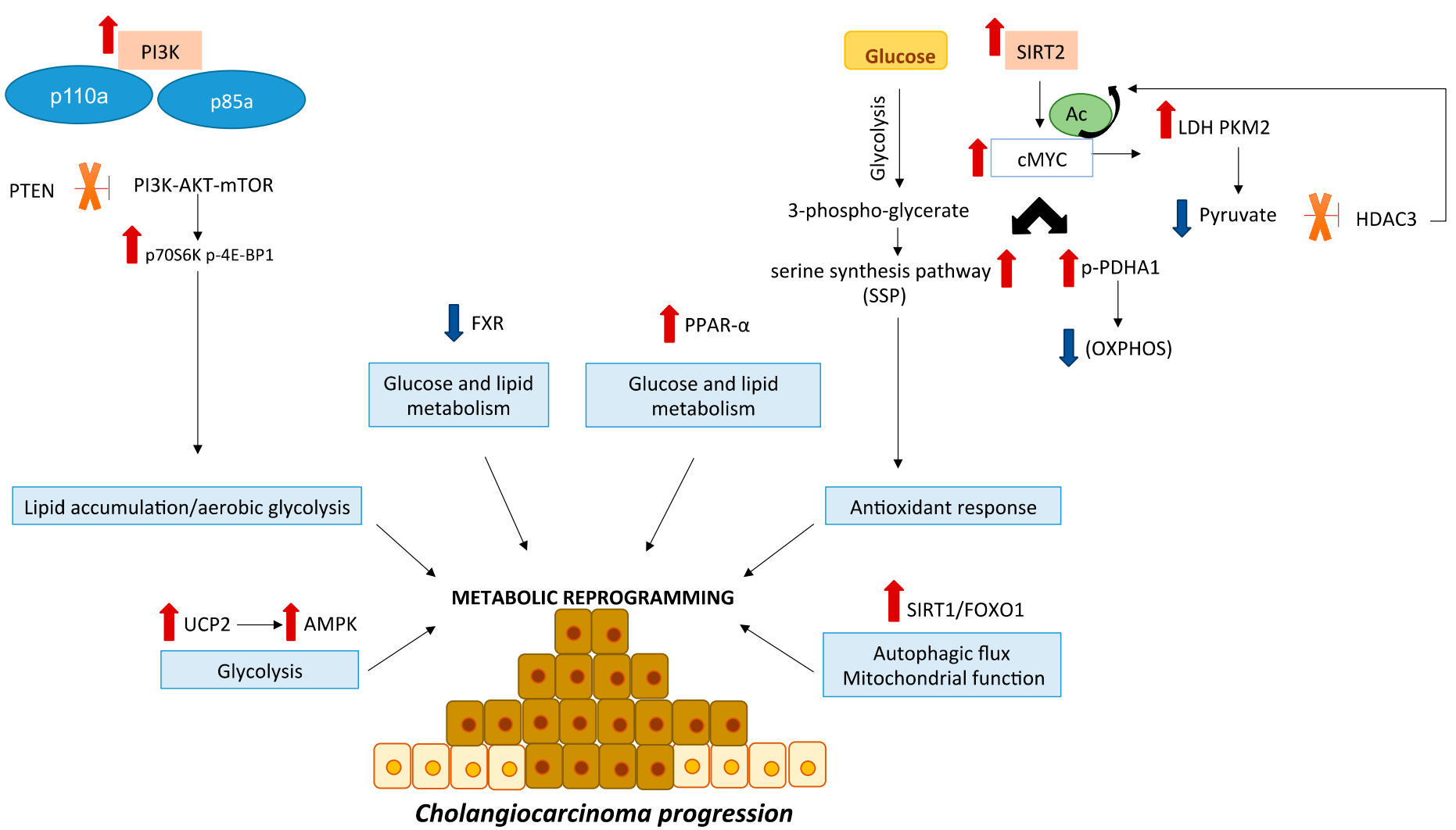

Figure 1. Crucial signaling pathways in CCA metabolism. The PI3K/AKT/mTOR pathway is an essential modulator of cell metabolism, growth and survival in CCA. Activating mutations of gene coding for the p110a and p85a subunits of PI3K and loss of the phosphatase and tensin homolog (PTEN) have been reported in CCA. Moreover, it has been shown the overexpression of downstream mTOR effectors, such as p70S6K and p-4E-BP1. SIRT2/cMYC pathway is overexpressed in CCA cell lines and mediates the activation of the PDHA1 by inhibition the OXPHOS as well as the activation of SSP that acts against ROS production. During CCA progression increase lactate levels while pyruvate levels decrease. Moreover, cMyc induces an increase of LDH and PKM2 expression, which afterwards reduces pyruvate levels. Being the pyruvate an HDAC3 inhibitor, a reduction of its levels removes HDAC3 inhibition and promotes cMyc overexpression. Sirt1/FOXO1 pathway is involved in autophagy and mitochondrial functions. UCP2 promotes CCA development through AMPK pathway. FXR expression is downregulated in human tissues and CCA cell lines inducing tumor progression by modulating cellular metabolism. PPAR- $\alpha$ is overexpressed in CCA patients and modulates several genes involved in glucose and lipid metabolism as well as immune responses. All these alterations induce the activation of pathways that promote CCA progression through a reprogramming of cellular metabolism. 


\subsection{PI3K-AKT-mTOR Signaling Pathway}

The signaling pathway PI3K-AKT-mTOR is one of the most frequently altered pathways in human cancer [131] and plays a critical role in tumorigenesis through the modulation of cellular metabolism, including glucose homeostasis, nutrients uptake and utilization. Its deregulated activation supports enhanced cancer cell growth and proliferation and drives tumor initiation and progression. The role of PI3K/AKT/mTOR pathway in human CCA has been assessed both in vitro and in vivo. The most common alterations include activating mutations and overexpression of the PI3K genes (PIK3CA and PIK3R1) that encode respectively for the p110a and p85a subunits [132]. PI3K is a lipid kinase that phosphorylates the $3^{\prime}$-hydroxyl group of the inositol ring of phosphatidylinositol to generate 3'-phosphoinositides [39]. Uncontrolled activation of this kinase causes accumulation of transit signals responsible for pathway triggering. Protein overexpression and functional activation of PI3K have been associated with tumor progression, differentiation, nodal involvement and reduced overall survival (OS) [40]. Positive immunostaining for unphosphorilated and phosphorylated form of AKT have been reported in human CCA specimens, with higher rates in neoplastic cells compared to the surrounding normal tissue [40]. Increased mTOR gene copy number and elevated phospho-mTOR levels have been described in biliary cancer specimens in comparison to the adjacent normal or dysplastic epithelium [41]. Moreover, several studies reported overexpression of downstream mTOR effectors in CCA. For example, high p70S6K expression has been associated with poor tumor differentiation [41] and high p-4E-BP1 level has been correlated with poor prognosis in a CCA patient's cohort [41]. The lipid phosphatase and tensin homologous (PTEN) is responsible for negative regulation of the pathway and inactivating mutations or deletion of PTEN lead to uncontrolled activation of PI3K/AKT/mTOR signaling. In fact, PTEN loss has been related to poor tumor differentiation, nodal involvement and shorter survival in CCA [42] (Table 1). Finally, several growth factor receptors have been involved in cholangiocarcinogenesis via PI3K/AKT/mTOR pathway. For example, EGFR/HER2-dependent PI3K/AKT phosphorylation has been demonstrated in CCA cell lines and human CCA tissue samples [133,134]. The PI3K/AKT/mTOR pathway acts downstream of insulin growth factor receptor 1 (IGFR1) in CCA tissues. Indeed IGFR1 inhibitors NVP-AEW541 [135] and BMS-536924 prevented AKT activation and exerted antiproliferative effects in CCA cells and in a xenograft CCA mouse model [136].

The studies described in this paragraph showed mutations, gene copy number alterations and aberrant protein phosphorylation of the key players of this pathway in CCA. These alterations lead to PI3K/AKT/mTOR pathway activation, which in turn triggers anabolic processes such as mRNA translation, protein synthesis and post-translational modulation of metabolic enzymes and switch to aerobic glycolysis, supporting enhanced growth, proliferation, chemoresistance.

Pre-clinical studies demonstrated that the following PI3K inhibitors, LY294002, Buparlisib (BKM120) and PI-103 have significant in vitro activity against CCA cells.

LY294002 inhibited cell proliferation, invasiveness and EMT [111] by decreasing p-AKT and p70S6K levels.

Buparlisib demonstrated important anti-proliferative activity in either mutant or wild-type KRAS CCA cells [112], while the inhibitor PI-103 affect cell proliferation in a xenograft CCA mouse model [113]. Clinical reports on the activity of PI3K inhibitors in CCA are limited. A Phase I trial evaluated the activity of mFOLFOX6 (modified Folinic acid/5-Fluorouracil/Oxaliplatin) combined with Buparlisib in 17 patients with advanced refractory gastrointestinal tumors ( 4 of whom were CCAs). The maximum tolerated dose (MTD) (primary endpoint) of Buparlisib was established at $40 \mathrm{mg}$. Only 8 patients out of 17 were treated for at least two cycles ( 8 weeks) and were evaluable for response. At the end of this study the authors concluded that the combination of mFOLFOX6 with Buparlisib resulted in increased toxicity compared to either treatment alone and did not prove efficacious in treatment of advanced refractory biliary tract malignancies ([114], Table 2).

In addition, Copanlisib is a pan-class I inhibitor of PI3K with predominant PI3K- $\alpha / \delta$ activity with clinical activity and manageable safety when administered as monotherapy in a phase II study. Kim and colleagues showed the results of a phase I study to determine the safety, tolerability and 
recommended phase II dose of Copanlisib in combination with Gemcitabine or with Cisplatin plus Gemcitabine (CisGem) in patients with advanced solid malignancies, including CCA [115].

Concerning AKT inhibitors the allosteric inhibitors (MK2206) or adenosine triphosphate (ATP)-competitive molecules proved to be effective to impair cell proliferation, survival and in different CCA cell lines [137,138].

MK2206 as an orally administered single agent was evaluated at the weekly dose of $200 \mathrm{mg}$ in a Phase II study enrolling 8 patients affected by advanced, pretreated CCAs. None of the 8 patients had an objective response and only two patients achieved stable disease (25\%) at 12weeks ([116], Table 2).

The pathway of mTOR was assessed in vitro using an mTOR inhibitor, Everolimus, showing dose-dependent decrease of cell proliferation by this molecule [139]. A phase I study reported that Everolimus achieved 50\% disease-control-rate in a subgroup of 22 advanced CCA patients ([104], Table 2). Subsequently a phase II study, in which patients with advanced CCA were enrolled, used Everolimus as a treatment option reporting an OS of 9.5 months [105]. At the same time in a phase II Italian study with Everolimus 39 patients with advanced and pre-treated CCA had progression-free survival (PFS) of 3.2 months, and OS of 7.7 months [106] while an Australian phase II study with Everolimus, conducted on patients with advanced CCA, showed objective response rate of $12 \%$ and PFS of 6.0 months. Recently in 27 unselected patients, Everolimus displayed clinical activity as first-line monotherapy in advanced CCA with PFS of 5.5 months and OS of 9.5 months [105]. In another phase II study that aimed to evaluate the activity of Everolimus in 10 patients with PIK3CA amplification/mutation or PTEN loss refractory solid cancer, only one patient with CCA with PTEN loss experienced disease control ([107], Table 2). Concerning other mTOR inhibitors, Rizell reported a cohort of Sirolimus used in patients with HCC $(n=21)$ and iCCA $(n=9)$. Three $(33 \%)$ of nine patients with iCCA achieved stable disease after Sirolimus treatment [108]. In a clinical study enrolling patients with PIK3CA mutant/amplified refractory solid cancer, Sirolimus failed to demonstrate the clinical benefit in a patient with hilar CCA (PIK3CA E545K mutation) who experienced disease progression following the second cycle of Sirolimus with PFS of 0.9 months ([109], Table 2). Regarding clinical trials using mTOR inhibitors and standard treatment, the only published study was performed to determine the MTD of different combinations of Everolimus and chemotherapeutic agents ([110], Table 2).

Despite several studies showed encouraging results more extensive investigations are necessary to elucidate the efficacy of mTOR inhibitors in the treatment of CCA.

\subsection{SIRT2/cMYC Signaling Pathway}

Recently, another pathway, sustained by a divergence of the glycolytic flux, has been described to have a crucial role in promoting CCA proliferation. It is known that the glycolytic intermediate 3-phospho-glycerate can be shunted to the serine synthesis pathway (SSP) to sustain an antioxidant response. Indeed, a metabolic reprogramming of CCA cells towards the production of anti-oxidant molecules may support cancer cell growth through the reduction of tumor oxidative stress [43]. $\mathrm{Xu} \mathrm{L}$. et al., [43] observed that the histone deacetylase sirtuin 2 (SIRT2) and its downstream target cMYC, were overexpressed both in two human CCA cell lines (HUCCT1 and RBE) with respect to normal bile duct epithelial cells and in 48 CCA samples compared to adjacent tissues. The SIRT2/cMYC pathway is able to reprogram CCA metabolism through: i) phosphorylation of the PDHA1 and hence inhibition of OXPHOS; ii) activation of SSP to counteract ROS production by increasing antioxidant defenses, thus protecting CCA cells from oxidative stress-induced apoptosis. Indeed, CCA patients with elevated expression levels of SIRT2, cMYC, and p-PDHA1 were associated with lower survival rates [43]. The same authors showed that CCA cells stabilized a positive feedback loop sustaining Warburg metabolism [43]. At this regard, it has been demonstrated that CCA cells, through an avid consumption of glucose, decreased the level of pyruvate in favor of increased levels of lactate. Actually, tumour cells induce a MYC-mediated increase of LDH and Pyruvate kinase isoenzyme M2 expression levels causing a decrease in pyruvate levels. Pyruvate is an inhibitor of the histone deacetylase HDAC3, which deacetylases cMYC at the K323 site, promoting its stabilization. Thus cMYC, 
by decreasing pyruvate levels, removes HDAC3 inhibition and sustains a positive feedback loop. This circuitry protects cancer cells from apoptosis [140]. Moreover, the high levels of carbon flux supply the increased production of metabolic intermediates, giving advantages in a challenging tumor microenvironment [141-143].

\subsection{Uncoupling Protein 2 (UCP2)}

$\mathrm{Yu} \mathrm{J}$ et al. [44] have produced another recent paper supporting the association of CCA with glycolysis. They showed that the uncoupling protein UCP2, promoting the proton leak to decrease the electrochemical potential and hence ATP synthesis, was up-regulated in human CCA and this event was associated with a worse prognosis. Up-regulation of UCP2 sustains the EMT and cell invasion. Indeed, in in vitro experiments they proved that inhibition of UCP2 suppressed cell proliferation and migration, reversed EMT, and reduced drug resistance as well as spheroid formation. Interestingly, all these events correlated with reduced glycolytic flux, reinforcing the idea that UCP2 contributes to the progression of CCA through a glycolysis-mediated mechanism [44] (Table 1).

\subsection{Transcription Factor FOXO1}

Autophagy plays a key role in the maintenance of cellular homeostasis. In healthy cells its homeostatic activity represents a robust barrier against malignant transformation and control of autophagy progression in cancer cells is an effective strategy to halt tumor growth [144]. Impaired autophagy could interfere with key cellular processes including energy metabolism control and mitochondrial dysfunction [145]. In CCA cell line QBC939, the authors demonstrated that the transcription factor FOXO1 regulated both basal and serum starvation-induced autophagy via the interaction between Acetylated-FOXO1 and Atg7. FOXO1 silencing or Sirt1 inhibition, affected autophagic flux, impaired mitochondrial function and induced apoptosis in a cholangiocarcinoma cell line, suggesting a role of Sirt1/FOXO1 pathway in the interplay between autophagy and mitochondrial dysfunction in CCA [50] (Table 1).

\subsection{Nuclear Receptors: Farnesoid X Receptor (FXR) and Peroxisome Proliferator Activated Receptor- $\alpha$ $($ PPAR- $\alpha)$}

The nuclear receptors have bi-functional activities, are capable of binding hormone as well as directly activating gene transcription. Nuclear receptors and their coregulators exhibit critical functions in the regulation of metabolic processes and they are central regulator of feeding and fasting state [146].

Among nuclear receptors, farnesoid X receptor (FXR) regulates bile acid homeostasis and it is activated in the fed state to exert a direct effect on metabolic pathways, including suppression of both gluconeogenesis and lipogenesis [147,148].

Rather, peroxisome proliferator-activated receptor- $\alpha$ (PPAR- $\alpha)$ is a well-known inducer of hepatic fatty acid oxidation in the fasted state and it promotes gluconeogenesis [149].

FXR and PPAR- $\alpha$ have opposite functions in metabolic mechanisms, that determine opposite effects on gluconeogenesis, indicating extensive functional interactions and conflicting metabolic effects.

The high expression of FXR was observed in tissues exposed to high bile acid concentration, including cholangiocytes, and this type of nuclear receptor is also involved in several processes such as lipid and glucose metabolism, fibrosis, and regeneration [150-153].

Moreover, Erice et al., [45] have recently shown a downregulation of FXR expression in both human tissues and CCA cell lines. They have found that the FXR agonist, obeticholic acid (OCA), inhibited the orthotopic CCA tumor growth in immunodeficient mice and this was associated with decreased expression of proliferation markers such as Ki67 and PCNA. Moreover, in vitro it has been demonstrated that OCA inhibited CCA cell proliferation and migration and these inhibitory effects of OCA on CCA cells were associated with decreased mitochondrial energy metabolism [45] (Table 1). 
Loss of FXR activity could be an important molecular event in the initiation and progression of $\mathrm{CCA}$, and the downregulation of FXR expression could promote cancer development, modulating the energy metabolism of CCA cells.

A further fundamental factor in CCA progression is PPAR- $\alpha$. In a recent study, there have been identified endogenous RNAs which modulated the expression of target genes, which could have a role in tumor occurrence and progression in patients with CCA. The analysis performed has revealed that the genes identified were strongly linked to metabolism. Pathway analysis has found that carbon metabolism, bile secretion, fat digestion, and PPAR signaling pathway were processes significantly enriched and played a pivotal role in CCA patients [46] (Table 1).

Recently, through the meta-analysis of CCA that represents a new systematical multivariate analysis tool, there have been identified 25 genes and five pathways associated with type 2 diabetes, obesity, and dyslipidemia. All five pathways were associated with the metabolism of lipids. Among these pathways, there was PPAR- $\alpha$ signaling which represents a significant modulator of numerous genes involved in glucose and lipid metabolism as well as inflammatory processes. PPAR- $\alpha$ in human liver determines also the down-regulation of several genes involved in various immunity-related pathways [47] (Table 1).

\subsection{Isocitrate Dehidrogenase (IDH)}

Isocitrate dehidrogenase enzymes play an important role in the TCA cycle, catalysing the oxidative decarboxylation of isocitrate to $\alpha$-ketoglutarate, producing carbon dioxide and NADPH [26]. Frequent mutations in the IDH1 and IDH2 genes have been shown in different types of cancer, including CCA $[154,155]$. IDH mutations (mIDH) are known as neomorphic mutations, since they give a new function to the product of the altered gene. Indeed, they establish a pathway for the NAPDH-dependent conversion of the wild-type IDH product, $\alpha$-ketoglutarate into 2-hydroxyglutarate (2-HG) [156] with a significant decrease in NADPH production [157] (Table 1). 2-HG is normally present as two enantiomers, dextrogyre $(D)$ and laevogyre $(L)$. Interestingly $\mathrm{mIDH}$ preferably provokes an increase in the $D$-enantiomer of 2-HG rather than the L-enantiomer and these forms can be measured in the serum by gas chromatography coupled to mass spectrometry [158] or liquid chromatography combined with mass spectrometry $[159,160]$.

In the most mIDH, the wild-type IDH function is lost due to mutation of critical amino acid residues in the catalytic domain, IDH1 R132 and IDH2 R172, which normally binds the b-carboxyl group of isocitrate to start catalysis [156,161].

In CCA, the most common mutations of IDH1 are R132C (more frequent), R132G and R132L, which are distinct from the $\mathrm{R} 132 \mathrm{H}$ mutation found in gliomas [155,162,163]; nevertheless, these activating alterations have been shown to increase the serum level of 2-HG in cholangiocarcinoma [160]. The prevalence of IDH2 mutations in CCA is instead R172K, R172M, and R172G [162].

Accumulating evidence identifies 2-HG as an oncometabolite, since it interferes with many regulatory pathways involving $\alpha$-ketoglutarate-dependent dioxygenases, including those implicated in epigenetic remodeling and DNA repair [164-166]. Indeed 2-HG hinders the function of enzymes that use $\alpha$-ketoglutarate as a co-enzyme, including histone and DNA demethylases, by competitively occupying the same pockets as $\alpha$-ketoglutarate $[167,168]$.

Genomic studies reported that mutations in IDH1/2 were found in approximately $10 \%$ (range, $5-36 \%$ ) of iCCA, whatever the geographical area of the world [154,169-171] while mutations in IDH1 were linked to iCCA with a prevalence of about $20 \%$ in North America [162].

The histological characteristics of CCA mIDH1 tumors are not well defined: they seem to vary from small duct types and unique geographic type fibrosis [172], to a large spectrum of histopathology features [155]; the discordancy could be due to the relatively small number of analyzed patients for each single study. Intriguingly, mIDH CCA tumors present definite molecular characteristics, including low levels of chromatin modifiers, upregulation of mitochondrial genes, as components of the TCA cycle and electron transport chain, and increased copy numbers of mitochondrial DNA [155]. Of note, mIDH 
hypermethylates ARID1A promoter can lower the chromatin remodeler expression [155]. A recent study on a large cohort of of iCCA patients $(n=496)$ based on occurrence of mutations in IDH, KRAS and TP53 genes, revealed unique mutational, structural and epigenetic features, which could facilitate prediction of therapeutic sensitivity for each iCCA patient, by evaluating individual genotyping [173]. It has been reported that mIDH occured mostly in woman with a percentage of about $60-70 \%$, a higher incidence than in the whole CCA population [174], and that three genes resulted often co-mutated with mIDH: ARID1A (22\%), BAP1 (15,5\%) and PBRM1 (13,3\%) [174].

Unfortunately none of the studies on $\mathrm{mIDH}$ have showed significant association between the presence of these alterations and clinopathological features (OS, PFS or time of progression) [174].

The high incidence of IDH mutations in numerous malignant tumors has promoted the development of specific inhibitor compounds resulting in several clinical trials.

AG-120 (Ivosidenib), an oral selective inhibitor of mIDH1 characterized by good tolerance, has displayed therapeutic activity with reduction of 2-HG levels in various solid tumors, including CCA [117]. In CCA patients treated with Ivosidenib, 6-month PFS was 38\% and 12-month PFS was $20 \% ; 56 \%$ of patients achieved stable disease and $5 \%$ achieved a partial response.

A follow-up trial in mutated IDH1 CCA patients that are not eligible for curative resection, transplantation, or ablative therapies prior to enrollment, is underway (NCT02989857) with completion date on 11/01/2019. Patients with IDH2 mutated solid tumors have been enrolled in a phase I-II clinical trial evaluating the orally bioavailable compound AG-221, an inhibitor of mutant IDH2 (NCT02273739) [118] (Table 2).

Very recently, it has been reported that IDH1 mutation in CCA enhanced the formation of intrahepatic biliary organoids (IBOs) and sped up the glucose uptake and glucose metabolism as well as upregulation of some metabolytes in TCA cycle (citrate, fumarate and malate). Interestingly platelet isoform of phosphofructokinse-1 (PFKP), a rate-limiting glycolytic enzyme, was also upregulated and knockdown of its gene reduced IBOs formation, indicating that the induction of glycolysis in mutant IBOs could occur by enhancing the expression of this enzyme. A direct link between the IDH 1 mutation and the expression of PFKP was demonstrated by the decrease of the protein level in mutant IBOs treated with AGI-5198 (a mIDH1 inhibitor) and the increase of the protein level in mutant IBOs treated with 2-HG (Table 2). In addition, mutant IBOs could sustain survival in ATP depletion conditions by obtaining ATP through the activation of AMPK. These results suggest that IDH mutation drives two-way metabolic rewiring status [48]. (Table 1).

\subsection{Tumor Suppressor p53}

In addition to oncogenes, tumor suppressors, like the p53 transcription factor, can regulate cancer metabolism [175]. The p53 canonical activity is related to cell cycle arrest, senescence, apoptosis and DNA repair, but recently it has been demonstrated that p53 results also involved in regulating cancer metabolism and oxidative stress [176,177]. Indeed loss of this protein causes an increased glycolytic flux to induce anabolism and redox balance that ultimately leads to tumorigenesis [175].

The p53 protein-encoding gene TP53 is mutated or deleted in 50\% of all human cancers [22]. Particularly in iCCA, while commonly harbors mutations affect IDH1/2, BAP1, KRAS, TP53, SMAD4, and ARID1A [178,179]. The p53 inactivation is the most common dysfunction (observed in $37 \%$ of iCCAs) [180,181], recently revealed as predictor of a poor prognosis [182]. The p53 is also involved in eCCA development and serum antibody against this protein was reported to be useful for the early detenction of this form of cancer $[183,184]$. Of note TP53 loss enhanced reprogramming of hepatocytes to biliary cells promoting CCA, pointing at p53 as a critical regulator of this process [185].

\subsection{Hif-1 $\alpha$ Signaling Pathway}

Nowadays, hypoxia is widely recognized as a critical tumor-promoting player. Hypoxia exerts a selective pressure on cancer cells, promoting the clonal expansion of the most aggressive tumor phenotypes. Cellular responses to hypoxia are primarily mediated by the activation of 
HIFs, i.e., helix-loop-helix transcription factors that bind to specific DNA sequences known as hypoxia-response elements. HIFs consist of two subunits: $\alpha$ (HIF- $1 \alpha$, HIF- $2 \alpha$, or HIF- $3 \alpha$ ) and $\beta$ (HIF-1 $\beta$ ). Among HIF- $\alpha$ isoforms, HIF- $1 \alpha$ is the best characterized, due to its ubiquitous expression. HIF- $1 \alpha$ is a master regulator of transcriptional response to low oxygen and it is associated with resistance to radiotherapies and chemotherapies and poor clinical outcome [186]. HIF-1 $\alpha$ promotes the transcription of several target genes involved in key cellular processes including glucose metabolism [187].

In CCA specimens, HIF- $1 \alpha$ is typically overexpressed compared to bile ducts of peritumoral areas [188], and its high expression was reported as an independent prognostic factor for overall and disease-free survival [189] (Table 1). Consistently, in vitro studies clearly demonstrated that hypoxia-induced signaling led CCA cells to gain a more malignant phenotype. For instance, low-oxygen culture conditions, as well as treatment with cobalt chloride (i.e., a chemical inducer of HIF-1 $\alpha$ ), promoted a substantial increase in CCA cell motility and invasiveness [190,191]. In a recent study the authors found that the hepatocyte growth factor (HGF) antagonist NK4 is effective on inhibiting CCA cell hypoxic growth and invasion both in vitro and in vivo. In particular, NK4 inhibited HIF-1 $\alpha$ expression and HIF-1-induced CCA cells invasion in vitro and tumor angiogenesis in vivo, suggesting an involvement of HGF/MET signaling on the CCA malignant phenotype promoted by HIF-1 $\alpha$ [192]. Moreover HIF- $1 \alpha$ regulated the expression of Rab1a via miR-212-3p. Rab1a is a member of RAS oncogene family and its overexpression activates mTORC1 signaling that plays a critical role in tumor metabolic reprogramming [193]. It has been demonstrated that Rab1a was overexpressed in iCCA tissues and associated with poor prognosis of iCCA patients and knockdown expression of HIF-1 $\alpha$ under hypoxia condition decreased the expression of Rabla expression while miR-212-3p was increased. Suppression of Rabla led to lower proliferation rate and migration ability both in vitro and in vivo by inhibiting cell cycle and EMT. In conclusion this study demonstrates that HIF- $1 \alpha / \mathrm{miR}-212-3 p / R a b 1 a$ axis, a well-known mTORC1 associated signalling, enhances proliferation and migration of CCA cells [194].

It has been described that HIF-1 is able to stimulate lipid accumulation through HIF-2 protein induction, a factor implicated in neutral lipids deposition into lipid droplets [195]. In addition, in the liver HIF2 is involved in changing of lipid metabolism in response of VHL lack. The specific liver-deletion of VHL in mice lead to steatosis, together with increased lipid droplets formation and Boxidation down-regulation [196]. The exact role of these lipid droplets in tumor development and survival is not fully understood, but it has been proposed that the storage of triacylglycerides could be useful in intermittent hypoxia conditions, since they can be utilized as a quickly available energy source after reoxygenation [96]. Although FAs utilization is crucial for cancer cells survival in hypoxic condition, indeed it seems that tumor cells preserve a certain grade of B-oxidation, as shown by CPT1C requirement [197]. In addition, it has been demonstrated that hypoxia also stimulated FASN expression, through Akt and SREBP1. To regulate FA biosynthesis, hypoxia is able to alter lipid composition of tumor cells, by impairing lipid synthesis and modification pathways on one hand and modifying exogenous lipids uptake on the other. In fact, a recent study showed how hypoxic tumor cells undertake lysophospholipids from the environment to meet the requirement of unsaturated FAs [198].

\section{Future Directions}

Several studies have shown that impaired metabolism in cancer cells may result in the generation of an unbalanced metabolically microenvironment [199]. In particular, the metabolic effects on immune cell phenotype have recently become of major interest [200-202].

Rising evidence have shown that crucial feature of immune cells such as activation, differentiation, as well as regulation of immune responses and immunological memory are strictly associated to their metabolic state. For instance, metabolism modulates macrophage polarization and consequently their functions. Conventionally, M1 macrophages mediate an inflammatory and antitumor response through glycolysis and reduced mitochondrial activity. Conversely, anti-inflammatory M2 macrophages show 
enhanced fatty acid oxidation and high OXPHOS as well as more mitochondria [203,204]. In M1 macrophages, glycolysis favours the introduction of the carbon flux into the oxidative PPP pathway, which produces NADPH for the generation of ROS via NADPH oxidases [205].

Further, M2 macrophages express specific changes in some metabolic pathways such as arginine metabolism that is moved toward the production of ornithine and polyamine by arginase I and II instead of citrulline and NO by inducible nitric oxide synthase (iNOS) [205,206].

Moreover, fatty acid oxidation supports the pro-tumor potential of M2 macrophages and provides a crucial energy source for M2 macrophage polarization. [202]. Additionally, it has been observed that the inhibition of fatty acid oxidation in tumor-associated macrophages promotes antitumorigenic differentiation and inhibits tumor growth [207].

Furthermore several findings indicate a key role of glycolysis in Treg proliferation in the tumor setting. Intra-tumoral Tregs show a high glucose uptake [208] and they have high levels of GLUT-1 on the cell surface, express high levels of glycolysis-related genes, and engage a higher glycolytic flux as measured in terms of extracellular acidification rate directly compared to effector T cells [209]. These evidences suggest that glycolysis may be involved in the maintenance and proliferation of tumorinfiltrating Tregs.

CCA growth is deeply affected by a multitude of immune cells. However, the consequences of the metabolic programming of immune cells on CCA progression are largely indeterminate and should be further studied in order to develop more effective combinatorial therapies.

Owing to the increasing focus of research on immune-modulating therapy options, knowledge of the molecular mechanisms underlying immune infiltration of CCA is of growing interest. The development of innovative approaches based on generating $\mathrm{T}$ cell products for immunotherapy requires the acquiring of new knowledge on metabolic aspects that favors anti-tumor function of T cells.

Overall, the emerging interfaces between metabolism and immune response: "immunometabolism" may allow identifying metabolic pathways that may modulate the immune response during CCA initiation and progression.

Author Contributions: C.R., F.M. critically revised the manuscript. All authors have read and agreed to the published version of the manuscript.

Funding: Funding for this work was partially provided by Italian Foundation of Cancer Research award (IG23117) to Dr. Raggi and (IG17786) to Prof. Marra.

Conflicts of Interest: The authors disclose no conflicts.

\begin{abstract}
Abbreviations
Cholangiocarcinoma (CCA), cancer stem cells (CSCs), peroxisome proliferator activated receptor gamma coactivator 1- $\alpha$ (PGC-1 $\alpha$ ), oxidative phosphorylation system (OXPHOS), tricarboxylic acid (TCA), hexosamine biosynthesis pathway (HBP), glucosamine-fructose-6-phosphate amidotransfrase (GFAT), pentose phosphate pathway (PPP), lactate dehydrogenase A (LDH-A, Pyruvate dehydrogenase kinases (PDKs), hypoxia inducible factor $\alpha(\mathrm{HIF} 1 \alpha)$, pyruvate dehydrogenase (PDHA1), phosphatidylinositol 3-kinase (PI3K), signal transducer and activator of transcription 3 (STAT3), nicotinamide adenine dinucleotide (NADH), nicotinamide adenine dinucleotide phosphate (NADPH), peroxisome proliferator-activated receptor (PPAR), free fatty acids (FFAs), fatty acids (FAs), triacylglycerides (TAGs), hydroxy-methylglutaryl (HMG-CoA), reactive oxygen species (ROS), cyclooxygenases (COX), prostaglandins (PG), growth factor receptors (GFRs), epidermal growth factor receptor (EGFR), fatty acid synthase (FASN), cluster of differentiation 36 (CD36), fatty acid transport proteins (FATPs), epithelial to mesenchymal transition (EMT), growth factor-beta (TGF $\beta$ ), tumor necrosis factor- $\alpha$ (TNF- $\alpha$ ), L-type amino acid transporter 1 (LAT1), argininosuccinate synthetase (ASS), hepatocellularcarcinoma (HCC), serine synthesis pathway (SSP), farnesoid X receptor (FXR), transferrin receptor (TfR1), ferroportin (Fpn), insulin growth factor receptor (IGFR1), uncoupling Protein 2 (UCP2), nMYC downstream-regulated gene 2 (NDRG2), obeticholic acid (OCA), isocitrate dehidrogenase (IDH), programmed death-ligand 1 (PD-L1), programmed cell death protein 1 (PD-1), platelet isoform of phosphofructokinse-1 (PFKP), intrahepatic biliary organoids (IBOs), hepatocyte growth factor (HGF), (cancer associated fibroblasts (CAFs), Vascular Endothelial Growth Factor (VEGF), Toll-like receptors (TLRs).
\end{abstract}




\section{References}

1. Steiner, P.E.; Higginson, J. Cholangiolocellular carcinoma of the liver. Cancer 1959, 12, 753-759. [CrossRef]

2. Bragazzi, M.C.; Ridola, L.; Safarikia, S.; Matteo, S.D.; Costantini, D.; Nevi, L.; Cardinale, V. New insights into cholangiocarcinoma: Multiple stems and related cell lineages of origin. Ann. Gastroenterol. 2018, 31, 42-55. [CrossRef]

3. Nakanuma, Y.; Kakuda, Y. Pathologic classification of cholangiocarcinoma: New concepts. Best Pract. Res. Clin. Gastroenterol. 2015, 29, 277-293. [CrossRef]

4. Sia, D.; Villanueva, A.; Friedman, S.L.; Llovet, J.M. Liver Cancer Cell of Origin, Molecular Class, and Effects on Patient Prognosis. Gastroenterology 2017, 152, 745-761. [CrossRef]

5. Krasinskas, A.M. Cholangiocarcinoma. Surg. Pathol. Clin. 2018, 11, 403-429. [CrossRef]

6. Oliveira, I.S.; Kilcoyne, A.; Everett, J.M.; Mino-Kenudson, M.; Harisinghani, M.G.; Ganesan, K. Cholangiocarcinoma: Classification, diagnosis, staging, imaging features, and management. Abdom. Radiol. 2017, 42, 1637-1649. [CrossRef]

7. Nakanuma, Y.; Sato, Y.; Harada, K.; Sasaki, M.; Xu, J.; Ikeda, H. Pathological classification of intrahepatic cholangiocarcinoma based on a new concept. World J. Hepatol. 2010, 2, 419-427. [CrossRef]

8. Deoliveira, M.L.; Schulick, R.D.; Nimura, Y.; Rosen, C.; Gores, G.; Neuhaus, P.; Clavien, P.A. New staging system and a registry for perihilar cholangiocarcinoma. Hepatology 2011, 53, 1363-1371. [CrossRef]

9. Bridgewater, J.; Galle, P.R.; Khan, S.A.; Llovet, J.M.; Park, J.W.; Patel, T.; Pawlik, T.M.; Gores, G.J. Guidelines for the diagnosis and management of intrahepatic cholangiocarcinoma. J. Hepatol. 2014, 60, 1268-1289. [CrossRef]

10. Rizvi, S.; Gores, G.J. Pathogenesis, diagnosis, and management of cholangiocarcinoma. Gastroenterology 2013, 145, 1215-1229. [CrossRef]

11. Javle, M.; Bekaii-Saab, T.; Jain, A.; Wang, Y.; Kelley, R.K.; Wang, K.; Kang, H.C.; Catenacci, D.; Ali, S.; Krishnan, S.; et al. Biliary cancer: Utility of next-generation sequencing for clinical management. Cancer 2016, 122, 3838-3847. [CrossRef]

12. Rizvi, S.; Gores, G.J. Emerging molecular therapeutic targets for cholangiocarcinoma. J. Hepatol. 2017, 67, 632-644. [CrossRef]

13. Forner, A.; Vidili, G.; Rengo, M.; Bujanda, L.; Ponz-Sarvisé, M.; Lamarca, A. Clinical presentation, diagnosis and staging of cholangiocarcinoma. Liver Int. 2019, 39 (Suppl. 1), 98-107. [CrossRef]

14. Banales, J.M.; Cardinale, V.; Carpino, G.; Marzioni, M.; Andersen, J.B.; Invernizzi, P.; Lind, G.E.; Folseraas, T.; Forbes, S.J.; Fouassier, L.; et al. Expert consensus document: Cholangiocarcinoma: Current knowledge and future perspectives consensus statement from the European Network for the Study of Cholangiocarcinoma (ENS-CCA). Nat. Rev. Gastroenterol. Hepatol. 2016, 13, 261-280. [CrossRef]

15. Patel, T. Worldwide trends in mortality from biliary tract malignancies. BMC Cancer 2002, 2, 10. [CrossRef]

16. Shaib, Y.H.; Davila, J.A.; McGlynn, K.; El-Serag, H.B. Rising incidence of intrahepatic cholangiocarcinoma in the United States: A true increase? J. Hepatol. 2004, 40, 472-477. [CrossRef]

17. Alvaro, D.; Crocetti, E.; Ferretti, S.; Bragazzi, M.C.; Capocaccia, R.; committee, A.C. Descriptive epidemiology of cholangiocarcinoma in Italy. Dig. Liver Dis. 2010, 42, 490-495. [CrossRef]

18. Rizvi, S.; Khan, S.A.; Hallemeier, C.L.; Kelley, R.K.; Gores, G.J. Cholangiocarcinoma-Evolving concepts and therapeutic strategies. Nat. Rev. Clin. Oncol. 2018, 15, 95-111. [CrossRef]

19. Clements, O.; Eliahoo, J.; Kim, J.U.; Taylor-Robinson, S.D.; Khan, S.A. Risk factors for intrahepatic and extrahepatic cholangiocarcinoma: A systematic review and meta-analysis. J. Hepatol. 2019, 72, 95-103. [CrossRef]

20. Lendvai, G.; Szekerczés, T.; Illyés, I.; Dóra, R.; Kontsek, E.; Gógl, A.; Kiss, A.; Werling, K.; Kovalszky, I.; Schaff, Z.; et al. Cholangiocarcinoma: Classification, Histopathology and Molecular Carcinogenesis. Pathol. Oncol. Res. 2018, 1-13. [CrossRef]

21. Pavlova, N.N.; Thompson, C.B. The Emerging Hallmarks of Cancer Metabolism. Cell Metab. 2016, 23, 27-47. [CrossRef]

22. DeBerardinis, R.J.; Chandel, N.S. Fundamentals of cancer metabolism. Sci. Adv. 2016, 2, e1600200. [CrossRef]

23. Wolpaw, A.J.; Dang, C.V. Exploiting Metabolic Vulnerabilities of Cancer with Precision and Accuracy. Trends Cell Biol. 2018, 28, 201-212. [CrossRef] 
24. Vergara, D.; Stanca, E.; Guerra, F.; Priore, P.; Gaballo, A.; Franck, J.; Simeone, P.; Trerotola, M.; De Domenico, S.; Fournier, I.; et al. $\beta$-Catenin Knockdown Affects Mitochondrial Biogenesis and Lipid Metabolism in Breast Cancer Cells. Front. Physiol. 2017, 8, 544. [CrossRef]

25. Agostinelli, C.; Carloni, S.; Limarzi, F.; Righi, S.; Laginestra, M.A.; Musuraca, G.; Fiorentino, M.; Napolitano, R.; Cuneo, A.; Vergara, D.; et al. The emerging role of GSK-3 $\beta$ in the pathobiology of classical Hodgkin lymphoma. Histopathology 2017, 71, 72-80. [CrossRef]

26. Sharma, A.; Boise, L.H.; Shanmugam, M. Cancer Metabolism and the Evasion of Apoptotic Cell Death. Cancers 2019, 11, 1144. [CrossRef]

27. Lunt, S.Y.; Vander Heiden, M.G. Aerobic glycolysis: Meeting the metabolic requirements of cell proliferation. Annu. Rev. Cell Dev. Biol. 2011, 27, 441-464. [CrossRef]

28. Yu, L.; Chen, X.; Wang, L.; Chen, S. The sweet trap in tumors: Aerobic glycolysis and potential targets for therapy. Oncotarget 2016, 7, 38908-38926. [CrossRef]

29. Fu, Y.; Liu, S.; Yin, S.; Niu, W.; Xiong, W.; Tan, M.; Li, G.; Zhou, M. The reverse Warburg effect is likely to be an Achilles' heel of cancer that can be exploited for cancer therapy. Oncotarget 2017, 8, 57813-57825. [CrossRef]

30. Wilde, L.; Roche, M.; Domingo-Vidal, M.; Tanson, K.; Philp, N.; Curry, J.; Martinez-Outschoorn, U. Metabolic coupling and the Reverse Warburg Effect in cancer: Implications for novel biomarker and anticancer agent development. Semin. Oncol. 2017, 44, 198-203. [CrossRef]

31. Brooks, G.A. Cell-cell and intracellular lactate shuttles. J. Physiol. 2009, 587, 5591-5600. [CrossRef]

32. Chiarugi, P.; Cirri, P. Metabolic exchanges within tumor microenvironment. Cancer Lett. 2016, 380, $272-280$. [CrossRef]

33. Kubo, Y.; Aishima, S.; Tanaka, Y.; Shindo, K.; Mizuuchi, Y.; Abe, K.; Shirabe, K.; Maehara, Y.; Honda, H.; Oda, Y. Different expression of glucose transporters in the progression of intrahepatic cholangiocarcinoma. Hum. Pathol. 2014, 45, 1610-1617. [CrossRef]

34. Ikeno, Y.; Seo, S.; Iwaisako, K.; Yoh, T.; Nakamoto, Y.; Fuji, H.; Taura, K.; Okajima, H.; Kaido, T.; Sakaguchi, S.; et al. Preoperative metabolic tumor volume of intrahepatic cholangiocarcinoma measured by. J. Transl. Med. 2018, 16, 95. [CrossRef]

35. Suzuki, H.; Komuta, M.; Bolog, A.; Yokobori, T.; Wada, S.; Araki, K.; Kubo, N.; Watanabe, A.; Tsukagoshi, M.; Kuwano, H. Relationship between 18-F-fluoro-deoxy-D-glucose uptake and expression of glucose transporter 1 and pyruvate kinase M2 in intrahepatic cholangiocarcinoma. Dig. Liver Dis. 2015, 47, 590-596. [CrossRef]

36. Qu, X.; Sheng, J.; Shen, L.; Su, J.; Xu, Y.; Xie, Q.; Wu, Y.; Zhang, X.; Sun, L. Autophagy inhibitor chloroquine increases sensitivity to cisplatin in QBC939 cholangiocarcinoma cells by mitochondrial ROS. PLoS ONE 2017, 12, e0173712. [CrossRef]

37. Sanmai, S.; Proungvitaya, T.; Limpaiboon, T.; Chua-On, D.; Seubwai, W.; Roytrakul, S.; Wongkham, S.; Wongkham, C.; Somintara, O.; Sangkhamanon, S.; et al. Serum pyruvate dehydrogenase kinase as a prognostic marker for cholangiocarcinoma. Oncol. Lett. 2019, 17, 5275-5282. [CrossRef]

38. Xu, L.; Li, Y.; Zhou, L.; Dorfman, R.G.; Liu, L.; Cai, R.; Jiang, C.; Tang, D.; Wang, Y.; Zou, X.; et al. SIRT3 elicited an anti-Warburg effect through HIF1 $\alpha /$ PDK1/PDHA1 to inhibit cholangiocarcinoma tumorigenesis. Cancer Med. 2019, 8, 2380-2391. [CrossRef]

39. Cantley, L.C. The phosphoinositide 3-kinase pathway. Science 2002, 296, 1655-1657. [CrossRef]

40. Moon, A.; Chin, S.; Kim, H.K.; Kwak, J.J.; Koh, E.S.; Kim, Y.W.; Jang, K.T. EGFR, COX2, p-AKT expression and PIK3CA mutation in distal extrahepatic bile duct carcinoma. Pathology 2016, 48, 35-40. [CrossRef]

41. Wang, Z.; Zheng, T.; Wu, Q.; Wang, J.; Wu, C. Immunohistochemical analysis of the mTOR pathway in intrahepatic cholangiocarcinoma. Neoplasma 2012, 59, 137-141. [CrossRef]

42. Chung, J.Y.; Hong, S.M.; Choi, B.Y.; Cho, H.; Yu, E.; Hewitt, S.M. The expression of phospho-AKT, phospho-mTOR, and PTEN in extrahepatic cholangiocarcinoma. Clin. Cancer Res. 2009, 15, 660-667. [CrossRef]

43. Xu, L.; Wang, L.; Zhou, L.; Dorfman, R.G.; Pan, Y.; Tang, D.; Wang, Y.; Yin, Y.; Jiang, C.; Zou, X.; et al. The SIRT2/cMYC Pathway Inhibits Peroxidation-Related Apoptosis in Cholangiocarcinoma through Metabolic Reprogramming. Neoplasia 2019, 21, 429-441. [CrossRef]

44. Yu, J.; Shi, L.; Shen, X.; Zhao, Y. UCP2 regulates cholangiocarcinoma cell plasticity via mitochondria-to-AMPK signals. Biochem. Pharmacol. 2019, 166, 174-184. [CrossRef] 
45. Erice, O.; Labiano, I.; Arbelaiz, A.; Santos-Laso, A.; Munoz-Garrido, P.; Jimenez-Agüero, R.; Olaizola, P.; Caro-Maldonado, A.; Martín-Martín, N.; Carracedo, A.; et al. Differential effects of FXR or TGR5 activation in cholangiocarcinoma progression. Biochim. Biophys. Acta Mol. Basis Dis. 2018, 1864, 1335-1344. [CrossRef]

46. Xu, F.; Zhao, Y.; Qin, G.; Huan, Y.; Li, L.; Gao, W. Comprehensive analysis of competing endogenous RNA networks associated with cholangiocarcinoma. Exp. Ther. Med. 2019, 18, 4103-4112. [CrossRef] [PubMed]

47. Chen, Y.C.; Xu, C.; Zhang, J.G.; Zeng, C.P.; Wang, X.F.; Zhou, R.; Lin, X.; Ao, Z.X.; Lu, J.M.; Shen, J.; et al. Multivariate analysis of genomics data to identify potential pleiotropic genes for type 2 diabetes, obesity and dyslipidemia using Meta-CCA and gene-based approach. PLoS ONE 2018, 13, e0201173. [CrossRef]

48. Fujiwara, H.; Tateishi, K.; Misumi, K.; Hayashi, A.; Igarashi, K.; Kato, H.; Nakatsuka, T.; Suzuki, N.; Yamamoto, K.; Kudo, Y.; et al. Mutant IDH1 confers resistance to energy stress in normal biliary cells through PFKP-induced aerobic glycolysis and AMPK activation. Sci. Rep. 2019, 9, 18859. [CrossRef]

49. Li, D.; Wang, C.; Ma, P.; Yu, Q.; Gu, M.; Dong, L.; Jiang, W.; Pan, S.; Xie, C.; Han, J.; et al. PGC1 $\alpha$ promotes cholangiocarcinoma metastasis by upregulating PDHA1 and MPC1 expression to reverse the Warburg effect. Cell Death Dis. 2018, 9, 466. [CrossRef]

50. He, W.; Zhang, A.; Qi, L.; Na, C.; Jiang, R.; Fan, Z.; Chen, J. FOXO1, a Potential Therapeutic Target, Regulates Autophagic Flux, Oxidative Stress, Mitochondrial Dysfunction, and Apoptosis in Human Cholangiocarcinoma QBC939 Cells. Cell Physiol. Biochem. 2018, 45, 1506-1514. [CrossRef]

51. Calvisi, D.F.; Wang, C.; Ho, C.; Ladu, S.; Lee, S.A.; Mattu, S.; Destefanis, G.; Delogu, S.; Zimmermann, A.; Ericsson, J.; et al. Increased lipogenesis, induced by AKT-mTORC1-RPS6 signaling, promotes development of human hepatocellular carcinoma. Gastroenterology 2011, 140, 1071-1083. [CrossRef] [PubMed]

52. Li, L.; Che, L.; Tharp, K.M.; Park, H.M.; Pilo, M.G.; Cao, D.; Cigliano, A.; Latte, G.; Xu, Z.; Ribback, S.; et al. Differential requirement for de novo lipogenesis in cholangiocarcinoma and hepatocellular carcinoma of mice and humans. Hepatology 2016, 63, 1900-1913. [CrossRef] [PubMed]

53. Nakagawa, R.; Hiep, N.C.; Ouchi, H.; Sato, Y.; Harada, K. Expression of fatty-acid-binding protein 5 in intrahepatic and extrahepatic cholangiocarcinoma: The possibility of different energy metabolisms in anatomical location. Med. Mol. Morphol. 2019, 53, 42-49. [CrossRef] [PubMed]

54. Endo, K.; Yoon, B.I.; Pairojkul, C.; Demetris, A.J.; Sirica, A.E. ERBB-2 overexpression and cyclooxygenase-2 up-regulation in human cholangiocarcinoma and risk conditions. Hepatology 2002, 36, 439-450. [CrossRef] [PubMed]

55. Hayashi, N.; Yamamoto, H.; Hiraoka, N.; Dono, K.; Ito, Y.; Okami, J.; Kondo, M.; Nagano, H.; Umeshita, K.; Sakon, M.; et al. Differential expression of cyclooxygenase-2 (COX-2) in human bile duct epithelial cells and bile duct neoplasm. Hepatology 2001, 34, 638-650. [CrossRef]

56. Chariyalertsak, S.; Sirikulchayanonta, V.; Mayer, D.; Kopp-Schneider, A.; Fürstenberger, G.; Marks, F.; Müller-Decker, K. Aberrant cyclooxygenase isozyme expression in human intrahepatic cholangiocarcinoma. Gut 2001, 48, 80-86. [CrossRef] [PubMed]

57. Sirica, A.E.; Lai, G.H.; Zhang, Z. Biliary cancer growth factor pathways, cyclo-oxygenase-2 and potential therapeutic strategies. J. Gastroenterol. Hepatol. 2001, 16, 363-372. [CrossRef] [PubMed]

58. Sirica, A.E.; Lai, G.H.; Endo, K.; Zhang, Z.; Yoon, B.I. Cyclooxygenase-2 and ERBB-2 in cholangiocarcinoma: Potential therapeutic targets. Semin. Liver Dis. 2002, 22, 303-313. [CrossRef]

59. Wappler, J.; Arts, M.; Röth, A.; Heeren, R.M.A.; Peter Neumann, U.; Olde Damink, S.W.; Soons, Z.; Cramer, T. Glutamine deprivation counteracts hypoxia-induced chemoresistance. Neoplasia 2020, 22, 22-32. [CrossRef]

60. Satriano, L.; Lewinska, M.; Rodrigues, P.M.; Banales, J.M.; Andersen, J.B. Metabolic rearrangements in primary liver cancers: Cause and consequences. Nat. Rev. Gastroenterol. Hepatol. 2019, 16, 748-766. [CrossRef]

61. Kaira, K.; Sunose, Y.; Ohshima, Y.; Ishioka, N.S.; Arakawa, K.; Ogawa, T.; Sunaga, N.; Shimizu, K.; Tominaga, H.; Oriuchi, N.; et al. Clinical significance of L-type amino acid transporter 1 expression as a prognostic marker and potential of new targeting therapy in biliary tract cancer. BMC Cancer 2013, 13, 482. [CrossRef] [PubMed]

62. Janpipatkul, K.; Suksen, K.; Borwornpinyo, S.; Jearawiriyapaisarn, N.; Hongeng, S.; Piyachaturawat, P.; Chairoungdua, A. Downregulation of LAT1 expression suppresses cholangiocarcinoma cell invasion and migration. Cell Signal. 2014, 26, 1668-1679. [CrossRef] [PubMed] 
63. Yothaisong, S.; Dokduang, H.; Anzai, N.; Hayashi, K.; Namwat, N.; Yongvanit, P.; Sangkhamanon, S.; Jutabha, P.; Endou, H.; Loilome, W. Inhibition of l-type amino acid transporter 1 activity as a new therapeutic target for cholangiocarcinoma treatment. Tumour. Biol. 2017, 39, 1010428317694545. [CrossRef] [PubMed]

64. Jamnongkan, W.; Thanan, R.; Techasen, A.; Namwat, N.; Loilome, W.; Intarawichian, P.; Titapun, A.; Yongvanit, P. Upregulation of transferrin receptor-1 induces cholangiocarcinoma progression via induction of labile iron pool. Tumour Biol. 2017, 39, 1010428317717655. [CrossRef]

65. Raggi, C.; Gammella, E.; Correnti, M.; Buratti, P.; Forti, E.; Andersen, J.B.; Alpini, G.; Glaser, S.; Alvaro, D.; Invernizzi, P.; et al. Dysregulation of Iron Metabolism in Cholangiocarcinoma Stem-like Cells. Sci. Rep. 2017, 7, 17667. [CrossRef]

66. Saengboonmee, C.; Seubwai, W.; Pairojkul, C.; Wongkham, S. High glucose enhances progression of cholangiocarcinoma cells via STAT3 activation. Sci. Rep. 2016, 6, 18995. [CrossRef]

67. Phoomak, C.; Vaeteewoottacharn, K.; Silsirivanit, A.; Saengboonmee, C.; Seubwai, W.; Sawanyawisuth, K.; Wongkham, C.; Wongkham, S. High glucose levels boost the aggressiveness of highly metastatic cholangiocarcinoma cells via O-GlcNAcylation. Sci. Rep. 2017, 7, 43842. [CrossRef]

68. Thonsri, U.; Seubwai, W.; Waraasawapati, S.; Sawanyawisuth, K.; Vaeteewoottacharn, K.; Boonmars, T.; Cha'on, U. Overexpression of lactate dehydrogenase A in cholangiocarcinoma is correlated with poor prognosis. Histol. Histopathol. 2017, 32, 503-510. [CrossRef]

69. Yu, Y.; Liao, M.; Liu, R.; Chen, J.; Feng, H.; Fu, Z. Overexpression of lactate dehydrogenase-A in human intrahepatic cholangiocarcinoma: Its implication for treatment. World J. Surg. Oncol. 2014, 12, 78. [CrossRef]

70. Wu, C.A.; Chao, Y.; Shiah, S.G.; Lin, W.W. Nutrient deprivation induces the Warburg effect through ROS/AMPK-dependent activation of pyruvate dehydrogenase kinase. Biochim. Biophys. Acta 2013, 1833, 1147-1156. [CrossRef]

71. Chaiteerakij, R.; Yang, J.D.; Harmsen, W.S.; Slettedahl, S.W.; Mettler, T.A.; Fredericksen, Z.S.; Kim, W.R.; Gores, G.J.; Roberts, R.O.; Olson, J.E.; et al. Risk factors for intrahepatic cholangiocarcinoma: Association between metformin use and reduced cancer risk. Hepatology 2013, 57, 648-655. [CrossRef] [PubMed]

72. Ling, S.; Feng, T.; Ke, Q.; Fan, N.; Li, L.; Li, Z.; Dong, C.; Wang, C.; Xu, F.; Li, Y.; et al. Metformin inhibits proliferation and enhances chemosensitivity of intrahepatic cholangiocarcinoma cell lines. Oncol. Rep. 2014, 31, 2611-2618. [CrossRef] [PubMed]

73. Jiang, X.; Ma, N.; Wang, D.; Li, F.; He, R.; Li, D.; Zhao, R.; Zhou, Q.; Wang, Y.; Zhang, F.; et al. Metformin inhibits tumor growth by regulating multiple miRNAs in human cholangiocarcinoma. Oncotarget 2015, 6, 3178-3194. [CrossRef]

74. Anastasiou, D.; Yu, Y.; Israelsen, W.J.; Jiang, J.K.; Boxer, M.B.; Hong, B.S.; Tempel, W.; Dimov, S.; Shen, M.; Jha, A.; et al. Pyruvate kinase M2 activators promote tetramer formation and suppress tumorigenesis. Nat. Chem. Biol. 2012, 8, 839-847. [CrossRef] [PubMed]

75. Yang, Z.; Zhang, X.; Roberts, R.O.; Roberts, L.R.; Chaiteerakij, R. Metformin does not improve survival of cholangiocarcinoma patients with diabetes. Hepatology 2016, 63, 667-668. [CrossRef] [PubMed]

76. Menendez, J.A.; Lupu, R. Fatty acid synthase and the lipogenic phenotype in cancer pathogenesis. Nat. Rev. Cancer 2007, 7, 763-777. [CrossRef] [PubMed]

77. Li, J.N.; Mahmoud, M.A.; Han, W.F.; Ripple, M.; Pizer, E.S. Sterol regulatory element-binding protein-1 participates in the regulation of fatty acid synthase expression in colorectal neoplasia. Exp. Cell Res. 2000, 261, 159-165. [CrossRef]

78. Swinnen, J.V.; Vanderhoydonc, F.; Elgamal, A.A.; Eelen, M.; Vercaeren, I.; Joniau, S.; Van Poppel, H.; Baert, L.; Goossens, K.; Heyns, W.; et al. Selective activation of the fatty acid synthesis pathway in human prostate cancer. Int. J. Cancer 2000, 88, 176-179. [CrossRef]

79. Yoon, S.; Lee, M.Y.; Park, S.W.; Moon, J.S.; Koh, Y.K.; Ahn, Y.H.; Park, B.W.; Kim, K.S. Up-regulation of acetyl-CoA carboxylase alpha and fatty acid synthase by human epidermal growth factor receptor 2 at the translational level in breast cancer cells. J. Biol. Chem. 2007, 282, 26122-26131. [CrossRef]

80. Baenke, F.; Peck, B.; Miess, H.; Schulze, A. Hooked on fat: The role of lipid synthesis in cancer metabolism and tumour development. Dis. Model. Mech. 2013, 6, 1353-1363. [CrossRef]

81. Li, L.; Pilo, G.M.; Li, X.; Cigliano, A.; Latte, G.; Che, L.; Joseph, C.; Mela, M.; Wang, C.; Jiang, L.; et al. Inactivation of fatty acid synthase impairs hepatocarcinogenesis driven by AKT in mice and humans. J. Hepatol. 2016, 64, 333-341. [CrossRef] [PubMed] 
82. Ho, C.; Wang, C.; Mattu, S.; Destefanis, G.; Ladu, S.; Delogu, S.; Armbruster, J.; Fan, L.; Lee, S.A.; Jiang, L.; et al. AKT (v-akt murine thymoma viral oncogene homolog 1 ) and $\mathrm{N}$-Ras (neuroblastoma ras viral oncogene homolog) coactivation in the mouse liver promotes rapid carcinogenesis by way of mTOR (mammalian target of rapamycin complex 1), FOXM1 (forkhead box M1)/SKP2, and c-Myc pathways. Hepatology 2012, 55, 833-845. [CrossRef] [PubMed]

83. Amemori, S.; Ootani, A.; Aoki, S.; Fujise, T.; Shimoda, R.; Kakimoto, T.; Shiraishi, R.; Sakata, Y.; Tsunada, S.; Iwakiri, R.; et al. Adipocytes and preadipocytes promote the proliferation of colon cancer cells in vitro. Am. J. Physiol. Gastrointest. Liver Physiol. 2007, 292, G923-G929. [CrossRef] [PubMed]

84. Tan, J.; Buache, E.; Chenard, M.P.; Dali-Youcef, N.; Rio, M.C. Adipocyte is a non-trivial, dynamic partner of breast cancer cells. Int. J. Dev. Biol. 2011, 55, 851-859. [CrossRef]

85. Fletcher, S.J.; Sacca, P.A.; Pistone-Creydt, M.; Coló, F.A.; Serra, M.F.; Santino, F.E.; Sasso, C.V.; Lopez-Fontana, C.M.; Carón, R.W.; Calvo, J.C.; et al. Human breast adipose tissue: Characterization of factors that change during tumor progression in human breast cancer. J. Exp. Clin. Cancer Res. 2017, 36, 26. [CrossRef]

86. Ito, R.; Narita, S.; Huang, M.; Nara, T.; Numakura, K.; Takayama, K.; Tsuruta, H.; Maeno, A.; Saito, M.; Inoue, T.; et al. The impact of obesity and adiponectin signaling in patients with renal cell carcinoma: A potential mechanism for the "obesity paradox". PLOS ONE 2017, 12, e0171615. [CrossRef]

87. Zi, X.; Lusch, A.; Blair, C.A.; Okhunov, Z.; Yokoyama, N.N.; Liu, S.; Baker, M.; Huynh, V.; Landman, J. Effect of perineoplasm perinephric adipose tissues on migration of clear cell renal cell carcinoma cells: A potential role of WNT signaling. Oncotarget 2016, 7, 53277-53288. [CrossRef]

88. Nie, J.; Zhang, J.; Wang, L.; Lu, L.; Yuan, Q.; An, F.; Zhang, S.; Jiao, Y. Adipocytes promote cholangiocarcinoma metastasis through fatty acid binding protein 4. J. Exp. Clin. Cancer Res. 2017, 36, 183. [CrossRef]

89. Wymann, M.P.; Schneiter, R. Lipid signalling in disease. Nat. Rev. Mol. Cell Biol. 2008, 9, 162-176. [CrossRef]

90. Han, C.; Leng, J.; Demetris, A.J.; Wu, T. Cyclooxygenase-2 promotes human cholangiocarcinoma growth: Evidence for cyclooxygenase-2-independent mechanism in celecoxib-mediated induction of p21waf1/cip1 and p27kip1 and cell cycle arrest. Cancer Res. 2004, 64, 1369-1376. [CrossRef]

91. Wu, T.; Leng, J.; Han, C.; Demetris, A.J. The cyclooxygenase-2 inhibitor celecoxib blocks phosphorylation of Akt and induces apoptosis in human cholangiocarcinoma cells. Mol. Cancer Ther. 2004, 3, 299-307. [PubMed]

92. Wu, T. Cyclooxygenase-2 and prostaglandin signaling in cholangiocarcinoma. Biochim. Biophys. Acta 2005, 1755, 135-150. [CrossRef] [PubMed]

93. Zhang, Z.; Lai, G.H.; Sirica, A.E. Celecoxib-induced apoptosis in rat cholangiocarcinoma cells mediated by Akt inactivation and Bax translocation. Hepatology 2004, 39, 1028-1037. [CrossRef] [PubMed]

94. Lai, G.H.; Zhang, Z.; Sirica, A.E. Celecoxib acts in a cyclooxygenase-2-independent manner and in synergy with emodin to suppress rat cholangiocarcinoma growth in vitro through a mechanism involving enhanced Akt inactivation and increased activation of caspases-9 and -3. Mol. Cancer Ther. 2003, 2, 265-271. [PubMed]

95. Poitout, V.; Robertson, R.P. Glucolipotoxicity: Fuel excess and beta-cell dysfunction. Endocr. Rev. 2008, 29, 351-366. [CrossRef]

96. Santos, C.R.; Schulze, A. Lipid metabolism in cancer. FEBS J. 2012, 279, 2610-2623. [CrossRef]

97. Shida, D.; Takabe, K.; Kapitonov, D.; Milstien, S.; Spiegel, S. Targeting SphK1 as a new strategy against cancer. Curr. Drug Targets 2008, 9, 662-673. [CrossRef]

98. Pyne, N.J.; El Buri, A.; Adams, D.R.; Pyne, S. Sphingosine 1-phosphate and cancer. Adv. Biol. Regul. 2018, 68, 97-106. [CrossRef]

99. Chen, M.H.; Yen, C.C.; Cheng, C.T.; Wu, R.C.; Huang, S.C.; Yu, C.S.; Chung, Y.H.; Liu, C.Y.; Chang, P.M.; Chao, Y.; et al. Identification of SPHK1 as a therapeutic target and marker of poor prognosis in cholangiocarcinoma. Oncotarget 2015, 6, 23594-23608. [CrossRef]

100. Gao, P.; Peterson, Y.K.; Smith, R.A.; Smith, C.D. Characterization of isoenzyme-selective inhibitors of human sphingosine kinases. PLoS ONE 2012, 7, e44543. [CrossRef]

101. French, K.J.; Zhuang, Y.; Maines, L.W.; Gao, P.; Wang, W.; Beljanski, V.; Upson, J.J.; Green, C.L.; Keller, S.N.; Smith, C.D. Pharmacology and antitumor activity of ABC294640, a selective inhibitor of sphingosine kinase-2. J. Pharmacol. Exp. Ther. 2010, 333, 129-139. [CrossRef] [PubMed]

102. Ding, X.; Chaiteerakij, R.; Moser, C.D.; Shaleh, H.; Boakye, J.; Chen, G.; Ndzengue, A.; Li, Y.; Zhou, Y.; Huang, S.; et al. Antitumor effect of the novel sphingosine kinase 2 inhibitor ABC294640 is enhanced by 
inhibition of autophagy and by sorafenib in human cholangiocarcinoma cells. Oncotarget 2016, 7, 20080-20092. [CrossRef] [PubMed]

103. Britten, C.D.; Garrett-Mayer, E.; Chin, S.H.; Shirai, K.; Ogretmen, B.; Bentz, T.A.; Brisendine, A.; Anderton, K.; Cusack, S.L.; Maines, L.W.; et al. A Phase I Study of ABC294640, a First-in-Class Sphingosine Kinase-2 Inhibitor, in Patients with Advanced Solid Tumors. Clin. Cancer Res. 2017, 23, 4642-4650. [CrossRef] [PubMed]

104. Verzoni, E.; Pusceddu, S.; Buzzoni, R.; Garanzini, E.; Damato, A.; Biondani, P.; Testa, I.; Grassi, P.; Bajetta, E.; de Braud, F.; et al. Safety profile and treatment response of everolimus in different solid tumors: An observational study. Future Oncol. 2014, 10, 1611-1617. [CrossRef]

105. Lau, D.K.; Tay, R.Y.; Yeung, Y.H.; Chionh, F.; Mooi, J.; Murone, C.; Skrinos, E.; Price, T.J.; Mariadason, J.M.; Tebbutt, N.C. Phase II study of everolimus (RAD001) monotherapy as first-line treatment in advanced biliary tract cancer with biomarker exploration: The RADiChol Study. Br. J. Cancer 2018, 118, 966-971. [CrossRef]

106. Buzzoni, R.; Pusceddu, S.; Bajetta, E.; De Braud, F.; Platania, M.; Iannacone, C.; Cantore, M.; Mambrini, A.; Bertolini, A.; Alabiso, O.; et al. Activity and safety of RAD001 (everolimus) in patients affected by biliary tract cancer progressing after prior chemotherapy: A phase II ITMO study. Ann. Oncol. 2014, 25, 1597-1603. [CrossRef]

107. Kim, S.T.; Lee, J.; Park, S.H.; Park, J.O.; Park, Y.S.; Kang, W.K.; Lim, H.Y. Prospective phase II trial of everolimus in PIK3CA amplification/mutation and/or PTEN loss patients with advanced solid tumors refractory to standard therapy. BMC Cancer 2017, 17, 211. [CrossRef]

108. Rizell, M.; Andersson, M.; Cahlin, C.; Hafström, L.; Olausson, M.; Lindnér, P. Effects of the mTOR inhibitor sirolimus in patients with hepatocellular and cholangiocellular cancer. Int. J. Clin. Oncol. 2008, 13, 66-70. [CrossRef]

109. Jung, K.S.; Lee, J.; Park, S.H.; Park, J.O.; Park, Y.S.; Lim, H.Y.; Kang, W.K.; Kim, S.T. Pilot study of sirolimus in patients with PIK3CA mutant/amplified refractory solid cancer. Mol. Clin. Oncol. 2017, 7, 27-31. [CrossRef]

110. Costello, B.A.; Borad, M.J.; Qi, Y.; Kim, G.P.; Northfelt, D.W.; Erlichman, C.; Alberts, S.R. Phase I trial of everolimus, gemcitabine and cisplatin in patients with solid tumors. Investig. New Drugs 2014, 32, 710-716. [CrossRef]

111. Leelawat, K.; Leelawat, S.; Narong, S.; Hongeng, S. Roles of the MEK1/2 and AKT pathways in CXCL12/CXCR4 induced cholangiocarcinoma cell invasion. World J. Gastroenterol. 2007, 13, 1561-1568. [CrossRef] [PubMed]

112. Jin, L.; Jin, M.H.; Nam, A.R.; Park, J.E.; Bang, J.H.; Oh, D.Y.; Bang, Y.J. Anti-tumor effects of NVP-BKM120 alone or in combination with MEK162 in biliary tract cancer. Cancer Lett. 2017, 411, 162-170. [CrossRef] [PubMed]

113. Guest, R.V.; Boulter, L.; Dwyer, B.J.; Kendall, T.J.; Man, T.Y.; Minnis-Lyons, S.E.; Lu, W.Y.; Robson, A.J.; Gonzalez, S.F.; Raven, A.; et al. Notch3 drives development and progression of cholangiocarcinoma. Proc. Natl. Acad. Sci. USA 2016, 113, 12250-12255. [CrossRef]

114. McRee, A.J.; Sanoff, H.K.; Carlson, C.; Ivanova, A.; O’Neil, B.H. A phase I trial of mFOLFOX6 combined with the oral PI3K inhibitor BKM120 in patients with advanced refractory solid tumors. Investig. New Drugs 2015, 33, 1225-1231. [CrossRef] [PubMed]

115. Kim, R.D.; Alberts, S.R.; Peña, C.; Genvresse, I.; Ajavon-Hartmann, A.; Xia, C.; Kelly, A.; Grilley-Olson, J.E. Phase I dose-escalation study of copanlisib in combination with gemcitabine or cisplatin plus gemcitabine in patients with advanced cancer. Br. J. Cancer 2018, 118, 462-470. [CrossRef]

116. Ahn, D.H.; Li, J.; Wei, L.; Doyle, A.; Marshall, J.L.; Schaaf, L.J.; Phelps, M.A.; Villalona-Calero, M.A.; Bekaii-Saab, T. Results of an abbreviated phase-II study with the Akt Inhibitor MK-2206 in Patients with Advanced Biliary Cancer. Sci. Rep. 2015, 5, 12122. [CrossRef] [PubMed]

117. Dhillon, S. Ivosidenib: First Global Approval. Drugs 2018, 78, 1509-1516. [CrossRef]

118. Mertens, J.C.; Rizvi, S.; Gores, G.J. Targeting cholangiocarcinoma. Biochim. Biophys. Acta Mol. Basis Dis. 2018, 1864, 1454-1460. [CrossRef]

119. Buranrat, B.; Senggunprai, L.; Prawan, A.; Kukongviriyapan, V. Simvastatin and atorvastatin as inhibitors of proliferation and inducers of apoptosis in human cholangiocarcinoma cells. Life Sci. 2016, 153, 41-49. [CrossRef]

120. Roeksomtawin, S.; Navasumrit, P.; Waraprasit, S.; Parnlob, V.; Sricharunrat, T.; Bhudhisawasdi, V.; Savaraj, N.; Ruchirawat, M. Decreased argininosuccinate synthetase expression in Thai patients with cholangiocarcinoma and the effects of ADI-PEG20 treatment in CCA cell lines. Oncol. Lett. 2018, 16, 1529-1538. [CrossRef] 
121. Abou-Alfa, G.K.; Qin, S.; Ryoo, B.Y.; Lu, S.N.; Yen, C.J.; Feng, Y.H.; Lim, H.Y.; Izzo, F.; Colombo, M.; Sarker, D.; et al. Phase III randomized study of second line ADI-PEG 20 plus best supportive care versus placebo plus best supportive care in patients with advanced hepatocellular carcinoma. Ann. Oncol. 2018, 29, 1402-1408. [CrossRef] [PubMed]

122. Chen, L.; Cui, H. Targeting Glutamine Induces Apoptosis: A Cancer Therapy Approach. Int. J. Mol. Sci. 2015, 16, 22830-22855. [CrossRef] [PubMed]

123. Liu, H.; Dong, H.; Robertson, K.; Liu, C. DNA methylation suppresses expression of the urea cycle enzyme carbamoyl phosphate synthetase 1 (CPS1) in human hepatocellular carcinoma. Am. J. Pathol. 2011, 178, 652-661. [CrossRef] [PubMed]

124. Murakami, Y.; Kubo, S.; Tamori, A.; Itami, S.; Kawamura, E.; Iwaisako, K.; Ikeda, K.; Kawada, N.; Ochiya, T.; Taguchi, Y.H. Comprehensive analysis of transcriptome and metabolome analysis in Intrahepatic Cholangiocarcinoma and Hepatocellular Carcinoma. Sci. Rep. 2015, 5, 16294. [CrossRef]

125. Gammella, E.; Recalcati, S.; Rybinska, I.; Buratti, P.; Cairo, G. Iron-induced damage in cardiomyopathy: Oxidative-dependent and independent mechanisms. Oxidative Med. Cell Longev. 2015, 2015, 230182. [CrossRef]

126. Recalcati, S.; Gammella, E.; Buratti, P.; Cairo, G. Molecular regulation of cellular iron balance. IUBMB Life 2017, 69, 389-398. [CrossRef]

127. Fonseca-Nunes, A.; Jakszyn, P.; Agudo, A. Iron and cancer risk-A systematic review and meta-analysis of the epidemiological evidence. Cancer Epidemiol. Biomark. Prev. 2014, 23, 12-31. [CrossRef]

128. Niederau, C.; Fischer, R.; Sonnenberg, A.; Stremmel, W.; Trampisch, H.J.; Strohmeyer, G. Survival and causes of death in cirrhotic and in noncirrhotic patients with primary hemochromatosis. N. Engl. J. Med. 1985, 313, 1256-1262. [CrossRef]

129. Torti, S.V.; Torti, F.M. Iron and cancer: More ore to be mined. Nat. Rev. Cancer 2013, 13, 342-355. [CrossRef]

130. Yang, W.S.; Stockwell, B.R. Ferroptosis: Death by Lipid Peroxidation. Trends Cell Biol. 2016, 26, 165-176. [CrossRef]

131. Engelman, J.A. Targeting PI3K signalling in cancer: Opportunities, challenges and limitations. Nat. Rev. Cancer 2009, 9, 550-562. [CrossRef]

132. Ocana, A.; Vera-Badillo, F.; Al-Mubarak, M.; Templeton, A.J.; Corrales-Sanchez, V.; Diez-Gonzalez, L.; Cuenca-Lopez, M.D.; Seruga, B.; Pandiella, A.; Amir, E. Activation of the PI3K/mTOR/AKT pathway and survival in solid tumors: Systematic review and meta-analysis. PLoS ONE 2014, 9, e95219. [CrossRef] [PubMed]

133. Pignochino, Y.; Sarotto, I.; Peraldo-Neia, C.; Penachioni, J.Y.; Cavalloni, G.; Migliardi, G.; Casorzo, L.; Chiorino, G.; Risio, M.; Bardelli, A.; et al. Targeting EGFR/HER2 pathways enhances the antiproliferative effect of gemcitabine in biliary tract and gallbladder carcinomas. BMC Cancer 2010, 10, 631. [CrossRef] [PubMed]

134. Treekitkarnmongkol, W.; Suthiphongchai, T. High expression of ErbB2 contributes to cholangiocarcinoma cell invasion and proliferation through AKT/p70S6K. World J. Gastroenterol. 2010, 16, 4047-4054. [CrossRef] [PubMed]

135. Wolf, S.; Lorenz, J.; Mössner, J.; Wiedmann, M. Treatment of biliary tract cancer with NVP-AEW541: Mechanisms of action and resistance. World J. Gastroenterol. 2010, 16, 156-166. [CrossRef] [PubMed]

136. Ohashi, H.; Adachi, Y.; Yamamoto, H.; Taniguchi, H.; Nosho, K.; Suzuki, H.; Arimura, Y.; Imai, K.; Carbone, D.P.; Shinomura, Y. Insulin-like growth factor receptor expression is associated with aggressive phenotypes and has therapeutic activity in biliary tract cancers. Cancer Sci. 2012, 103, 252-261. [CrossRef]

137. Wilson, J.M.; Kunnimalaiyaan, S.; Kunnimalaiyaan, M.; Gamblin, T.C. Inhibition of the AKT pathway in cholangiocarcinoma by MK2206 reduces cellular viability via induction of apoptosis. Cancer Cell Int. 2015, 15, 13. [CrossRef]

138. Frampton, G.; Invernizzi, P.; Bernuzzi, F.; Pae, H.Y.; Quinn, M.; Horvat, D.; Galindo, C.; Huang, L.; McMillin, M.; Cooper, B.; et al. Interleukin-6-driven progranulin expression increases cholangiocarcinoma growth by an Akt-dependent mechanism. Gut 2012, 61, 268-277. [CrossRef]

139. Moolthiya, P.; Tohtong, R.; Keeratichamroen, S.; Leelawat, K. Role of mTOR inhibitor in cholangiocarcinoma cell progression. Oncol. Lett. 2014, 7, 854-860. [CrossRef] 
140. Zhang, M.; Pan, Y.; Tang, D.; Dorfman, R.G.; Xu, L.; Zhou, Q.; Zhou, L.; Wang, Y.; Li, Y.; Yin, Y.; et al. Low levels of pyruvate induced by a positive feedback loop protects cholangiocarcinoma cells from apoptosis. Cell Commun. Signal. 2019, 17, 23-37. [CrossRef]

141. Shaw, R.J. Glucose metabolism and cancer. Curr. Opin. Cell Biol. 2006, 18, 598-608. [CrossRef] [PubMed]

142. Bui, T.; Thompson, C.B. Cancer's sweet tooth. Cancer Cell 2006, 9, 419-420. [CrossRef] [PubMed]

143. Garber, K. Energy deregulation: Licensing tumors to grow. Science 2006, 312, 1158-1159. [CrossRef] [PubMed]

144. Wang, P.; Zhu, L.; Sun, D.; Gan, F.; Gao, S.; Yin, Y.; Chen, L. Natural products as modulator of autophagy with potential clinical prospects. Apoptosis 2017, 22, 325-356. [CrossRef] [PubMed]

145. Kimmelman, A.C.; White, E. Autophagy and Tumor Metabolism. Cell Metab. 2017, 25, 1037-1043. [CrossRef]

146. Preidis, G.A.; Kim, K.H.; Moore, D.D. Nutrient-sensing nuclear receptors PPAR $\alpha$ and FXR control liver energy balance. J. Clin. Investig. 2017, 127, 1193-1201. [CrossRef]

147. Schaap, F.G.; Trauner, M.; Jansen, P.L. Bile acid receptors as targets for drug development. Nat. Rev. Gastroenterol. Hepatol. 2014, 11, 55-67. [CrossRef]

148. Matsubara, T.; Li, F.; Gonzalez, F.J. FXR signaling in the enterohepatic system. Mol. Cell Endocrinol. 2013, 368, 17-29. [CrossRef]

149. Kersten, S. Integrated physiology and systems biology of PPAR $\alpha$. Mol. Metab. 2014, 3, 354-371. [CrossRef]

150. Zhu, C.; Fuchs, C.D.; Halilbasic, E.; Trauner, M. Bile acids in regulation of inflammation and immunity: Friend or foe? Clin. Exp. Rheumatol. 2016, 34, 25-31.

151. Vaquero, J.; Briz, O.; Herraez, E.; Muntané, J.; Marin, J.J. Activation of the nuclear receptor FXR enhances hepatocyte chemoprotection and liver tumor chemoresistance against genotoxic compounds. Biochim. Biophys. Acta 2013, 1833, 2212-2219. [CrossRef] [PubMed]

152. Gadaleta, R.M.; van Erpecum, K.J.; Oldenburg, B.; Willemsen, E.C.; Renooij, W.; Murzilli, S.; Klomp, L.W.; Siersema, P.D.; Schipper, M.E.; Danese, S.; et al. Farnesoid X receptor activation inhibits inflammation and preserves the intestinal barrier in inflammatory bowel disease. Gut 2011, 60, 463-472. [CrossRef] [PubMed]

153. Zhang, L.; Wang, Y.D.; Chen, W.D.; Wang, X.; Lou, G.; Liu, N.; Lin, M.; Forman, B.M.; Huang, W. Promotion of liver regeneration/repair by farnesoid $X$ receptor in both liver and intestine in mice. Hepatology 2012, 56, 2336-2343. [CrossRef]

154. Borger, D.R.; Tanabe, K.K.; Fan, K.C.; Lopez, H.U.; Fantin, V.R.; Straley, K.S.; Schenkein, D.P.; Hezel, A.F.; Ancukiewicz, M.; Liebman, H.M.; et al. Frequent mutation of isocitrate dehydrogenase (IDH)1 and IDH2 in cholangiocarcinoma identified through broad-based tumor genotyping. Oncologist 2012, 17, 72-79. [CrossRef] [PubMed]

155. Farshidfar, F.; Zheng, S.; Gingras, M.C.; Newton, Y.; Shih, J.; Robertson, A.G.; Hinoue, T.; Hoadley, K.A.; Gibb, E.A.; Roszik, J.; et al. Integrative Genomic Analysis of Cholangiocarcinoma Identifies Distinct IDH-Mutant Molecular Profiles. Cell Rep. 2017, 19, 2878-2880. [CrossRef] [PubMed]

156. Dang, L.; White, D.W.; Gross, S.; Bennett, B.D.; Bittinger, M.A.; Driggers, E.M.; Fantin, V.R.; Jang, H.G.; Jin, S.; Keenan, M.C.; et al. Cancer-associated IDH1 mutations produce 2-hydroxyglutarate. Nature 2009, 462, 739-744. [CrossRef]

157. Bleeker, F.E.; Atai, N.A.; Lamba, S.; Jonker, A.; Rijkeboer, D.; Bosch, K.S.; Tigchelaar, W.; Troost, D.; Vandertop, W.P.; Bardelli, A.; et al. The prognostic IDH1(R132) mutation is associated with reduced NADP+-dependent IDH activity in glioblastoma. Acta Neuropathol. 2010, 119, 487-494. [CrossRef]

158. Janin, M.; Mylonas, E.; Saada, V.; Micol, J.B.; Renneville, A.; Quivoron, C.; Koscielny, S.; Scourzic, L.; Forget, S.; Pautas, C.; et al. Serum 2-hydroxyglutarate production in IDH1- and IDH2-mutated de novo acute myeloid leukemia: A study by the Acute Leukemia French Association group. J. Clin. Oncol. 2014, 32, 297-305. [CrossRef]

159. Poinsignon, V.; Mercier, L.; Nakabayashi, K.; David, M.D.; Lalli, A.; Penard-Lacronique, V.; Quivoron, C.; Saada, V.; De Botton, S.; Broutin, S.; et al. Quantitation of isocitrate dehydrogenase (IDH)-induced D and $\mathrm{L}$ enantiomers of 2-hydroxyglutaric acid in biological fluids by a fully validated liquid tandem mass spectrometry method, suitable for clinical applications. J. Chromatogr. B Anal. Technol. BioMed Life Sci. 2016, 1022, 290-297. [CrossRef]

160. Delahousse, J.; Verlingue, L.; Broutin, S.; Legoupil, C.; Touat, M.; Doucet, L.; Ammari, S.; Lacroix, L.; Ducreux, M.; Scoazec, J.Y.; et al. Circulating oncometabolite D-2-hydroxyglutarate enantiomer is a surrogate marker of isocitrate dehydrogenase-mutated intrahepatic cholangiocarcinomas. Eur. J. Cancer 2018, 90, 83-91. [CrossRef] 
161. Ward, P.S.; Patel, J.; Wise, D.R.; Abdel-Wahab, O.; Bennett, B.D.; Coller, H.A.; Cross, J.R.; Fantin, V.R.; Hedvat, C.V.; Perl, A.E.; et al. The common feature of leukemia-associated IDH1 and IDH2 mutations is a neomorphic enzyme activity converting alpha-ketoglutarate to 2-hydroxyglutarate. Cancer Cell 2010, 17, 225-234. [CrossRef] [PubMed]

162. Kipp, B.R.; Voss, J.S.; Kerr, S.E.; Barr Fritcher, E.G.; Graham, R.P.; Zhang, L.; Highsmith, W.E.; Zhang, J.; Roberts, L.R.; Gores, G.J.; et al. Isocitrate dehydrogenase 1 and 2 mutations in cholangiocarcinoma. Hum. Pathol. 2012, 43, 1552-1558. [CrossRef] [PubMed]

163. Goyal, L.; Govindan, A.; Sheth, R.A.; Nardi, V.; Blaszkowsky, L.S.; Faris, J.E.; Clark, J.W.; Ryan, D.P.; Kwak, E.L.; Allen, J.N.; et al. Prognosis and Clinicopathologic Features of Patients With Advanced Stage Isocitrate Dehydrogenase (IDH) Mutant and IDH Wild-Type Intrahepatic Cholangiocarcinoma. Oncologist 2015, 20, 1019-1027. [CrossRef] [PubMed]

164. Madala, H.R.; Punganuru, S.R.; Arutla, V.; Misra, S.; Thomas, T.J.; Srivenugopal, K.S. Beyond Brooding on Oncometabolic Havoc in IDH-Mutant Gliomas and AML: Current and Future Therapeutic Strategies. Cancers 2018, 10, 49. [CrossRef]

165. Xu, W.; Yang, H.; Liu, Y.; Yang, Y.; Wang, P.; Kim, S.H.; Ito, S.; Yang, C.; Xiao, M.T.; Liu, L.X.; et al. Oncometabolite 2-hydroxyglutarate is a competitive inhibitor of $\alpha$-ketoglutarate-dependent dioxygenases. Cancer Cell 2011, 19, 17-30. [CrossRef]

166. Clark, O.; Yen, K.; Mellinghoff, I.K. Molecular Pathways: Isocitrate Dehydrogenase Mutations in Cancer. Clin. Cancer Res. 2016, 22, 1837-1842. [CrossRef]

167. Fu, X.; Chin, R.M.; Vergnes, L.; Hwang, H.; Deng, G.; Xing, Y.; Pai, M.Y.; Li, S.; Ta, L.; Fazlollahi, F.; et al. 2-Hydroxyglutarate Inhibits ATP Synthase and mTOR Signaling. Cell Metab. 2015, 22, 508-515. [CrossRef]

168. Parker, S.J.; Metallo, C.M. Metabolic consequences of oncogenic IDH mutations. Pharmacol. Ther. 2015, 152, 54-62. [CrossRef]

169. Voss, J.S.; Holtegaard, L.M.; Kerr, S.E.; Fritcher, E.G.; Roberts, L.R.; Gores, G.J.; Zhang, J.; Highsmith, W.E.; Halling, K.C.; Kipp, B.R. Molecular profiling of cholangiocarcinoma shows potential for targeted therapy treatment decisions. Hum. Pathol. 2013, 44, 1216-1222. [CrossRef]

170. Borger, D.R.; Goyal, L.; Yau, T.; Poon, R.T.; Ancukiewicz, M.; Deshpande, V.; Christiani, D.C.; Liebman, H.M.; Yang, H.; Kim, H.; et al. Circulating oncometabolite 2-hydroxyglutarate is a potential surrogate biomarker in patients with isocitrate dehydrogenase-mutant intrahepatic cholangiocarcinoma. Clin. Cancer Res. 2014, 20, 1884-1890. [CrossRef]

171. Ong, C.K.; Subimerb, C.; Pairojkul, C.; Wongkham, S.; Cutcutache, I.; Yu, W.; McPherson, J.R.; Allen, G.E.; $\mathrm{Ng}$, C.C.; Wong, B.H.; et al. Exome sequencing of liver fluke-associated cholangiocarcinoma. Nat. Genet. 2012, 44, 690-693. [CrossRef] [PubMed]

172. Wang, T.; Drill, E.; Vakiani, E.; Pak, L.M.; Boerner, T.; Askan, G.; Schvartzman, J.M.; Simpson, A.L.; Jarnagin, W.R.; Sigel, C.S. Distinct histomorphological features are associated with IDH1 mutation in intrahepatic cholangiocarcinoma. Hum. Pathol. 2019, 91, 19-25. [CrossRef] [PubMed]

173. Nepal, C.; O’Rourke, C.J.; Oliveira, D.V.N.P.; Taranta, A.; Shema, S.; Gautam, P.; Calderaro, J.; Barbour, A.; Raggi, C.; Wennerberg, K.; et al. Genomic perturbations reveal distinct regulatory networks in intrahepatic cholangiocarcinoma. Hepatology 2018, 68, 949-963. [CrossRef]

174. Boscoe, A.N.; Rolland, C.; Kelley, R.K. Frequency and prognostic significance of isocitrate dehydrogenase 1 mutations in cholangiocarcinoma: A systematic literature review. J. Gastrointest. Oncol. 2019, 10, 751-765. [CrossRef] [PubMed]

175. Kruiswijk, F.; Labuschagne, C.F.; Vousden, K.H. p53 in survival, death and metabolic health: A lifeguard with a licence to kill. Nat. Rev. Mol. Cell Biol. 2015, 16, 393-405. [CrossRef] [PubMed]

176. Jiang, L.; Kon, N.; Li, T.; Wang, S.J.; Su, T.; Hibshoosh, H.; Baer, R.; Gu, W. Ferroptosis as a p53-mediated activity during tumour suppression. Nature 2015, 520, 57-62. [CrossRef] [PubMed]

177. Li, T.; Kon, N.; Jiang, L.; Tan, M.; Ludwig, T.; Zhao, Y.; Baer, R.; Gu, W. Tumor suppression in the absence of p53-mediated cell-cycle arrest, apoptosis, and senescence. Cell 2012, 149, 1269-1283. [CrossRef]

178. Nakamura, H.; Arai, Y.; Totoki, Y.; Shirota, T.; Elzawahry, A.; Kato, M.; Hama, N.; Hosoda, F.; Urushidate, T.; Ohashi, S.; et al. Genomic spectra of biliary tract cancer. Nat. Genet. 2015, 47, 1003-1010. [CrossRef]

179. Jusakul, A.; Cutcutache, I.; Yong, C.H.; Lim, J.Q.; Huang, M.N.; Padmanabhan, N.; Nellore, V.; Kongpetch, S.; $\mathrm{Ng}$, A.W.T.; Ng, L.M.; et al. Whole-Genome and Epigenomic Landscapes of Etiologically Distinct Subtypes of Cholangiocarcinoma. Cancer Discov. 2017, 7, 1116-1135. [CrossRef] 
180. Torre, L.A.; Bray, F.; Siegel, R.L.; Ferlay, J.; Lortet-Tieulent, J.; Jemal, A. Global cancer statistics, 2012. CA Cancer J. Clin. 2015, 65, 87-108. [CrossRef]

181. Isomoto, H.; Kobayashi, S.; Werneburg, N.W.; Bronk, S.F.; Guicciardi, M.E.; Frank, D.A.; Gores, G.J. Interleukin 6 upregulates myeloid cell leukemia-1 expression through a STAT3 pathway in cholangiocarcinoma cells. Hepatology 2005, 42, 1329-1338. [CrossRef] [PubMed]

182. Simbolo, M.; Vicentini, C.; Ruzzenente, A.; Brunelli, M.; Conci, S.; Fassan, M.; Mafficini, A.; Rusev, B.; Corbo, V.; Capelli, P.; et al. Genetic alterations analysis in prognostic stratified groups identified TP53 and ARID1A as poor clinical performance markers in intrahepatic cholangiocarcinoma. Sci. Rep. 2018, 8, 7119. [CrossRef] [PubMed]

183. Shimada, H.; Ochiai, T.; Nomura, F.; Group, J.A.R. Titration of serum p53 antibodies in 1,085 patients with various types of malignant tumors: A multiinstitutional analysis by the Japan p53 Antibody Research Group. Cancer 2003, 97, 682-689. [CrossRef]

184. Okada, R.; Shimada, H.; Otsuka, Y.; Tsuchiya, M.; Ishii, J.; Katagiri, T.; Maeda, T.; Kubota, Y.; Nemoto, T.; Kaneko, H. Serum p53 antibody as a potential tumor marker in extrahepatic cholangiocarcinoma. Surg. Today 2017, 47, 1492-1499. [CrossRef] [PubMed]

185. Hill, M.A.; Alexander, W.B.; Guo, B.; Kato, Y.; Patra, K.; O’Dell, M.R.; McCall, M.N.; Whitney-Miller, C.L.; Bardeesy, N.; Hezel, A.F. Kras and Tp53 Mutations Cause Cholangiocyte- and Hepatocyte-Derived Cholangiocarcinoma. Cancer Res. 2018, 78, 4445-4451. [CrossRef] [PubMed]

186. Lin, D.; Wu, J. Hypoxia inducible factor in hepatocellular carcinoma: A therapeutic target. World J. Gastroenterol. 2015, 21, 12171-12178. [CrossRef] [PubMed]

187. Nagao, A.; Kobayashi, M.; Koyasu, S.; Chow, C.C.T.; Harada, H. HIF-1-Dependent Reprogramming of Glucose Metabolic Pathway of Cancer Cells and Its Therapeutic Significance. Int. J. Mol. Sci. 2019, 20, 238. [CrossRef]

188. Morine, Y.; Shimada, M.; Utsunomiya, T.; Imura, S.; Ikemoto, T.; Mori, H.; Hanaoka, J.; Kanamoto, M.; Iwahashi, S.; Miyake, H. Hypoxia inducible factor expression in intrahepatic cholangiocarcinoma. Hepatogastroenterology 2011, 58, 1439-1444. [CrossRef]

189. Thongchot, S.; Yongvanit, P.; Loilome, W.; Seubwai, W.; Phunicom, K.; Tassaneeyakul, W.; Pairojkul, C.; Promkotra, W.; Techasen, A.; Namwat, N. High expression of HIF-1 $\alpha$, BNIP3 and PI3KC3: Hypoxia-induced autophagy predicts cholangiocarcinoma survival and metastasis. Asian Pac. J. Cancer Prev. 2014, 15, 5873-5878. [CrossRef]

190. Vanichapol, T.; Leelawat, K.; Hongeng, S. Hypoxia enhances cholangiocarcinoma invasion through activation of hepatocyte growth factor receptor and the extracellular signal-regulated kinase signaling pathway. Mol. Med. Rep. 2015, 12, 3265-3272. [CrossRef]

191. Thongchot, S.; Loilome, W.; Yongvanit, P.; Dokduang, H.; Thanan, R.; Techasen, A.; Namwat, N. Chloroquine exerts anti-metastatic activities under hypoxic conditions in cholangiocarcinoma cells. Asian Pac. J. Cancer Prev. 2015, 16, 2031-2035. [CrossRef] [PubMed]

192. Xie, R.; Li, Q.; Ge, X.; Nie, J.; Wang, F.; Xu, B.; Pan, Z.; Miao, L. NK4 suppresses cholangiocarcinoma angiogenesis and invasion through targeting HIF-1 $\alpha$ pathway. Int. J. Clin. Exp. Med. 2017, 10, 2345-2352.

193. Thomas, J.D.; Zhang, Y.J.; Wei, Y.H.; Cho, J.H.; Morris, L.E.; Wang, H.Y.; Zheng, X.F.S. Rab1A Is an mTORC1 Activator and a Colorectal Oncogene. Cancer Cell 2016, 30, 181-182. [CrossRef] [PubMed]

194. Hou, P.; Kang, Y.; Luo, J. Hypoxia-mediated miR-212-3p downregulation enhances progression of intrahepatic cholangiocarcinoma through upregulation of Rab1a. Cancer Biol. Ther. 2018, 19,984-993. [CrossRef] [PubMed]

195. Krishnan, J.; Suter, M.; Windak, R.; Krebs, T.; Felley, A.; Montessuit, C.; Tokarska-Schlattner, M.; Aasum, E.; Bogdanova, A.; Perriard, E.; et al. Activation of a HIF1alpha-PPARgamma axis underlies the integration of glycolytic and lipid anabolic pathways in pathologic cardiac hypertrophy. Cell Metab. 2009, 9, 512-524. [CrossRef]

196. Rankin, E.B.; Rha, J.; Selak, M.A.; Unger, T.L.; Keith, B.; Liu, Q.; Haase, V.H. Hypoxia-inducible factor 2 regulates hepatic lipid metabolism. Mol. Cell Biol. 2009, 29, 4527-4538. [CrossRef]

197. Zaugg, K.; Yao, Y.; Reilly, P.T.; Kannan, K.; Kiarash, R.; Mason, J.; Huang, P.; Sawyer, S.K.; Fuerth, B.; Faubert, B.; et al. Carnitine palmitoyltransferase 1C promotes cell survival and tumor growth under conditions of metabolic stress. Genes Dev. 2011, 25, 1041-1051. [CrossRef] 
198. Kamphorst, J.J.; Cross, J.R.; Fan, J.; de Stanchina, E.; Mathew, R.; White, E.P.; Thompson, C.B.; Rabinowitz, J.D. Hypoxic and Ras-transformed cells support growth by scavenging unsaturated fatty acids from lysophospholipids. Proc. Natl. Acad. Sci. USA 2013, 110, 8882-8887. [CrossRef]

199. Dang, C.V.; Kim, J.W. Convergence of Cancer Metabolism and Immunity: An Overview. Biomol. Ther. 2018, 26, 4-9. [CrossRef]

200. O’Neill, L.A.; Kishton, R.J.; Rathmell, J. A guide to immunometabolism for immunologists. Nat. Rev. Immunol. 2016, 16, 553-565. [CrossRef]

201. Haschemi, A.; Kosma, P.; Gille, L.; Evans, C.R.; Burant, C.F.; Starkl, P.; Knapp, B.; Haas, R.; Schmid, J.A.; Jandl, C.; et al. The sedoheptulose kinase CARKL directs macrophage polarization through control of glucose metabolism. Cell Metab. 2012, 15, 813-826. [CrossRef] [PubMed]

202. Huang, S.C.; Everts, B.; Ivanova, Y.; O'Sullivan, D.; Nascimento, M.; Smith, A.M.; Beatty, W.; Love-Gregory, L.; Lam, W.Y.; O'Neill, C.M.; et al. Cell-intrinsic lysosomal lipolysis is essential for alternative activation of macrophages. Nat. Immunol. 2014, 15, 846-855. [CrossRef] [PubMed]

203. Tacke, F. Targeting hepatic macrophages to treat liver diseases. J. Hepatol. 2017, 66, 1300-1312. [CrossRef] [PubMed]

204. Tavakoli, S.; Zamora, D.; Ullevig, S.; Asmis, R. Bioenergetic profiles diverge during macrophage polarization: Implications for the interpretation of 18F-FDG PET imaging of atherosclerosis. J. Nucl. Med. 2013, 54, 1661-1667. [CrossRef] [PubMed]

205. Mehla, K.; Singh, P.K. Metabolic Regulation of Macrophage Polarization in Cancer. Trends Cancer 2019, 5, 822-834. [CrossRef] [PubMed]

206. Movahedi, K.; Laoui, D.; Gysemans, C.; Baeten, M.; Stangé, G.; Van den Bossche, J.; Mack, M.; Pipeleers, D.; In't Veld, P.; De Baetselier, P.; et al. Different tumor microenvironments contain functionally distinct subsets of macrophages derived from Ly6C(high) monocytes. Cancer Res. 2010, 70, 5728-5739. [CrossRef] [PubMed]

207. Niu, Z.; Shi, Q.; Zhang, W.; Shu, Y.; Yang, N.; Chen, B.; Wang, Q.; Zhao, X.; Chen, J.; Cheng, N.; et al. Caspase-1 cleaves PPAR $\gamma$ for potentiating the pro-tumor action of TAMs. Nat. Commun. 2017, 8, 766. [CrossRef]

208. Ho, P.C.; Bihuniak, J.D.; Macintyre, A.N.; Staron, M.; Liu, X.; Amezquita, R.; Tsui, Y.C.; Cui, G.; Micevic, G.; Perales, J.C.; et al. Phosphoenolpyruvate Is a Metabolic Checkpoint of Anti-tumor T Cell Responses. Cell 2015, 162, 1217-1228. [CrossRef]

209. Pacella, I.; Procaccini, C.; Focaccetti, C.; Miacci, S.; Timperi, E.; Faicchia, D.; Severa, M.; Rizzo, F.; Coccia, E.M.; Bonacina, F.; et al. Fatty acid metabolism complements glycolysis in the selective regulatory $\mathrm{T}$ cell expansion during tumor growth. Proc. Natl. Acad. Sci. USA 2018, 115, E6546-E6555. [CrossRef] 